Research Report No. 44/2009

\title{
Review Article: Bainbridge's The New Corporate Governance (in Context)
}

Fenner L. Stewart Jr.

Follow this and additional works at: http://digitalcommons.osgoode.yorku.ca/clpe

\section{Recommended Citation}

Stewart, Fenner L. Jr., "Review Article: Bainbridge's The New Corporate Governance (in Context)" (2009). Comparative Research in Law \& Political Economy. Research Paper No. 44/2009.

http://digitalcommons.osgoode.yorku.ca/clpe/153 


\section{Comparative Research in Law \& Political Economy}

Fenner L. Stewart

Review Article: Bainbridge's The New Corporate Governance (in Context)

EDITORS: Peer Zumbansen (Osgoode Hall Law School, Toronto, Director, Comparative Research in Law and Political Economy, York University), John W. Cioffi (University of California at Riverside), Nassim Nasser (Osgoode Hall Law School, Toronto, Production Editor) 

CLPE Research Paper 44/2009

Vol. 05 No. 08 (2009)

Fenner L. Stewart

\title{
Review Article: Bainbridge's The New Corporate Governance (IN CONTEXT)
}

\author{
The New Corporate Governance in Theory and Practice. By Stephen M. Bainbridge* . New York: \\ Oxford University Press, 2008. Pp. 245. \$60.00.
}

\begin{abstract}
If corporate boards are becoming more than "rubber stamps", then Stephen Bainbridge and his new book are in the middle of a coup d'état in corporate governance. On the other hand, if this shift is not occurring and boards remain "rubber stamps", then director primacy is no more than managerialism with a twist. Moreover, if director primacy represents the emergence of a new order for American corporate governance, then the merits of maintaining Delaware's status quo director primacy must be carefully assessed, because the stakes are changing - maybe for the better and maybe for the worse.

This article traces what has been argued in the literature to date. Part II will briefly refresh the reader's memory by presenting one narrative of how the American corporate governance debate emerged. Part III will provide a concise chapter-by-chapter roadmap for Bainbridge's arguments in The New Corporate Governance. Part VI will take a closer look at what Bainbridge tacitly suggests is the genius of Delaware's corporate law by mapping the debates which have raged over managerialism, state competition, and Delaware: America's regulatory laboratory for de facto "national" corporate law. This will provide a snapshot of the context from which The New Corporate Governance has emerged. Part V will conclude the review article by offering some reflections on what place the book holds within today's American corporate governance debate.
\end{abstract}

Keywords: Theory Review, Corporate Governance, Stephen M. Bainbridge

JEL classification: B25, G30, K22, G38

Fenner L. Stewart

Acting Academic Director of the Comparative Research in Law and Political Economy Network, and Ph.D. Candidate and Adjunct Professor of Law at Osgoode Hall Law School, Toronto.

\footnotetext{
${ }^{*}$ William D. Warren Professor of Law at University of California, Los Angeles.
} 


\title{
Review ArTiCle: Bainbridge's The New Corporate Governance (IN CONTEXT)
}

The New Corporate Governance in Theory and Practice. By Stephen M. Bainbridge* New York: Oxford University Press, 2008. Pp. 245. \$60.00.

\author{
Fenner L. Stewart, Jr.
}

\section{TABLE OF CONTENTS}

\section{INTRODUCTION}

\section{The Origins of CoRporate GovernanCe In THE AMERICAN CONTEXT}

A. From Personal Capitalism to Managerial Capitalism and Beyond

B. Berle's Protest Against Managerialism

C. Shareholder Primacy Reconceived: The Seeds of Corporate Contractarianism

\section{A Summary of The NeW Corporate GovernanCE}

A. Introduction

B. Chapter One

C. Chapter Two

D. Chapter Three

E. Chapter Four

F. Chapter Five

\section{The Myth AND Mystic OF Delaware: Bainbridge in CONTEXT}

\footnotetext{
${ }^{*}$ William D. Warren Professor of Law at University of California, Los Angeles.
}

* Acting Academic Director of the Comparative Research in Law and Political Economy Network, and Ph.D. Candidate and Adjunct Professor of Law at Osgoode Hall Law School, Toronto. I thank Stephen Bainbridge, Mark Roe and Peer Zumbansen for their helpful comments and encouragement on a draft copy of this article. 


\section{A. Historical Introduction}

B. The First Wave: Drawing the Distinction

C. The Second Wave: Event Studies and the Attempts to Settle the Cary-Winter Debate

D. The Third Wave: Post-Enron

E. The Delaware Dynamic: Berle-Dodd, Berle-Manne, Cary-Winter, Romano-Eisenberg, Bebchuk-Bainbridge, and Strine? and Roe? and Bratton?

F. The Battle for "Delaware": form or substance?

\section{CONCLUSION}

A. Putting the pieces together 


\section{INTRODUCTION}

Stephen Bainbridge's standing in the American corporate governance debate is not open to question. He enjoys a status similar to that of E. Merrick Dodd in his heyday. Bainbridge may not like this comparison, for his writings indicate that he would reject being labeled a managerialist. Admittedly, drawing a connection between Bainbridge and Dodd warps an accurate appreciation of the conceptual underpinnings of the American corporate governance debate. ${ }^{1}$ The managerialist debate over the firm as a political actor within the context of Welfare statism in the 1930s is much different than the feud over the proper function of the firm as a market actor within the context of financialization today. ${ }^{2}$ Yet from a distance, the comparison appears to stand, considering that the consequences of Bainbridge's director primacy position are still the same as those of managerialism in one important respect: both empower managers. And this comparison will remain standing at least until such time as the boards of America's large public corporations start behaving in the manner that Bainbridge suggests they will do in the future.

Even with federal initiatives to bolster director independence, Bainbridge himself acknowledges the Panoglossian nature of being optimistic about the present potential for director primacy today, fully acknowledging the problems of directors side-stepping their accountability on-thebooks to important constituents, like shareholders. ${ }^{3}$ And yet, just under the surface of American corporate law (which has always enshrined director primacy in a wink-wink, nudge-nudge sort of a way) may be another managerial revolution, ${ }^{4}$ which will blur the classic distinctions between shareholder/manager and managerialist/anti-managerialist by encouraging the board of directors to take their duties more seriously. The director primacy norms may cause directors to start

\footnotetext{
${ }^{1}$ Recent scholarship challenges whether today's casting of A. A. Berle as the original ancestor of the shareholder primacy position and of E. M. Dodd as the original ancestor of the corporate responsibility movement is altogether accurate. For instance, Bratton and Wachter argue that such castings may be misplaced, because modern audiences read Berle and Dodd without an appreciation for the context from which they wrote. They go so far as to suggest that the context of Berle and Dodd is "so far removed from that existing today as to block either side from a legitimate claim to direct ancestry". See William W. Bratton and Michael L. Wachter, Shareholder Primacy's Corporatist Origins: Adolf Berle and 'The Modern Corporation', 34 J. of Corp. L. 99, 104 (2008) [hereinafter Bratton \& Wachter, Corporatist Origins].

${ }^{2}$ See Peer Zumbansen, The Evolution of the Corporation: Organization, Finance, Knowledge and Corporate Social Responsibility (2009). CLPE Research Paper No. 6/2009. Available at SSRN: http://ssrn.com/abstract=1346971 [hereinafter Zumbansen, Evolution of the Corporation]. And also, see FenNer L. STEWART, JR., THE ROLE OF LAW in the CONSTRUCtion OF SOCIETAL GOVERNANCE AND CORPORATE ReSPONSIBILITY Chapter 4 (forthcoming 2010) [hereinafter Stewart, Role of Law].

${ }^{3}$ Stephen M. Bainbridge, The New Corporate GovernanCe in Theory and Practice 98-99, 103-104, $192-$ 194, 200 and 233 (2008) [hereinafter Bainbridge, Corporate Governance].

${ }^{4}$ The first Managerialist revolution occurred with the contractarian shift to "the Market" in the 1970s, which resulted in managers shifting their focus away from balancing the constituent interests of the firm and towards maximizing shareholder value.
} 
standing up to the special interests of managers and protecting shareholder interests more diligently. As a result, this may foster a better relationship between ownership and control.

Bainbridge's new book, The New Corporate Governance in Theory and Practice, is a book that will not surprise anyone familiar with Bainbridge's publications. This book distills many of the arguments that Bainbridge has published since 2001, including: (1) his articles that establish the director primacy theory; ${ }^{5}(2)$ his articles that defend group decision-making in the context of the board of directors as a fiat; ${ }^{6}$ (3) his articles that explore the relationship between the courts (in particular Delaware) and corporate governance (in the context of director primacy) $;^{7}$ and (4) his articles that warn against the extension of the shareholder franchise beyond the present status quo $^{8}$.

${ }^{5}$ For example, see Stephen M. Bainbridge, The Board of Directors as Nexus of Contracts, 88 Iowa L. Rev. 1 (2002)
(introducing the conceptual foundation for his theory of director primacy). Also, see Stephen M. Bainbridge,
Director Primacy: The Means and Ends of Corporate Governance, 97 Nw. U. L. Rev. 547 (2003) (revisiting
director primacy, including decision-making by fiat, the primacy of the board of directors over shareholders and
managers, the relationship between the director primacy model and the nexus of contracts model, and the
importance of centralized decision-making for efficient corporate governance by balancing the need for balancing
authority and accountability within corporate regulation).

${ }^{6}$ For example, see Stephen M. Bainbridge, Why a Board? Group Decisionmaking in Corporate Governance, 55 Vand. L. Rev. 1 (2002) (exploring into why the default statutory model of corporate governance promotes a governance group that acts collegially, using evidence from the behavioral sciences to explain why group decisionmaking is generally superior to individual decision-making).

${ }^{7}$ For example, see Stephen M. Bainbridge, The creeping federalization of corporate law, 2003 Regulation 26 (2003) [hereinafter: Bainbridge, creeping federalization] (protesting the preemption of state corporate law by NYSE'S standards and Sarbanes-Oxley legislation, arguing that competitive federalism supports a market for regulatory innovations that promotes freedom and shareholder value). Also, see Stephen M. Bainbridge, The Business Judgment Rule as Abstention Doctrine, 57 Vand. L. Rev. 83 (2004) (reviewing the Delaware supreme courts decisions as regards the business judgment rule, determining that there are two competing views of the application of the rule: 1) as a standard of liability (more interventionist); and 2) as a doctrine of abstention (less interventionist), and argueing that since directors cannot be made more accountable without infringing their authority/discretion, courts ought to maintain the doctrine of abstention (unless there is evidence of self-dealing), because there will be a cost to efficient and dynamic corporate decision-making). Also, see Stephen M. Bainbridge, UNOCAL at 20: Director Primacy in Corporate Takeovers, 31 Del. J. Corp. L. 769 (2006) (defending Unocal Corp. v. Mesa Petroleum Co., which argues that the case finds a balance between protecting the authority/discretion of the board from shareholder and judicial oversight and ensuring director accountability - especially in relation to shareholder wealth maximization).

${ }^{8}$ For example see Stephen M. Bainbridge, Director v. Shareholder Primacy in the Convergence Debate, 16 Transnat'l L. 45 (2002) (clarifying that most scholars in the convergence debate assume that American corporate law primarily promotes shareholder primacy, when it actually promotes director primacy, warning that such confusion may have serious consequences when transplanting the American model into recipient jurisdictions). Also, see Stephen M. Bainbridge, Shareholder Activism and Institutional Investors, UCLA School of Law, Law-Econ Research Paper No. 05-20 (2005), available at SSRN: http://ssrn.com/abstract=796227 (warning against the dangers of greater institutional investor activism, arguing that such investors are motivation by narrow interest that may undermine passive investors and compromise the effectiveness of the board to make decision in the best interest of the firm). Also see Stephen M. Bainbridge, The Case for Limited Shareholder Voting Rights, 53 UCLA L. Rev. 601 (2006) (petitioning for greater prudence before extending the shareholder franchise, by defending why only shareholders have voting rights and then defending why such voting rights are so limited). Also, see Stephen M. Bainbridge, Director Primacy and Shareholder Disempowerment, 119 Harv. L. Rev. 1735 (2006) [hereinafter 
Bainbridge suggests that his new book, unlike so many other publications today, does not have an agenda to advocate for the reform of the statutory allocation of power within corporate governance. Rather, he expresses that his goal is to simply understand and clarify what this statutory allocation of power is, particularly in the context of Delaware's off-the-rack default statutory model of corporate governance. ${ }^{9}$ Taking this declaration at face value, one would anticipate that Bainbridge's book would be more descriptive than prescriptive, however this is not the case. If, as Bainbridge puts it: "boards are becoming change agents rather than rubber stamps" ${ }^{10}$, then defending the status quo director power, at a time of a managerial revolution that encourages directors to become "change agents", would place Bainbridge and his book in the middle of a coup d'état in corporate governance. This may be the reason Bainbridge entitles his book The New Corporate Governance. On the other hand, if this shift is not occurring and boards remain "rubber stamps", then director primacy is no more than managerialism with a twist.

If Bainbridge is correct and director primacy represents the emergence of a new order for American corporate governance, then the merits of maintaining Delaware's status quo director primacy must be carefully assessed, because the stakes are changing - maybe for the better and maybe for the worse. If this assessment can be made, it will demand an understanding of the American context from which Delaware's standards emerged. In other words, there needs to be a way of assessing: 1) who are shareholders and what are their interests; 2) who are managers and what are their interests; and 3) who are directors, what is their emerging role, and how this may effect the balance between shareholders' and managers' interests in the future. The problem in making such assessments is that generalizing about any of these groups (whether one uses rational choice theory, ${ }^{11}$ social choice theory, ${ }^{12}$ a variety of experimental economics and psychology, ${ }^{13}$ or majoritarian default theory ${ }^{14}$ ) is that their "interests" become no more than mere

Bainbridge, Director Primacy] (responding to Lucian A. Bebchuk's article entitled: The Case for Increasing Shareholder Power by rejecting Bebchuk's proposals for allowing shareholders to have greater voting power so that they can change a firm's basic corporate governance arrangements, while defending the existing regime of limited shareholder voting rights).

${ }^{9}$ Bainbridge, Corporate Governance, supra note 3, at x.

${ }^{10}$ Bainbridge, Corporate Governance, supra note 3, at 2.

11 For examples of the use of rational choice theory, see PAUL A. SAMUELSON, FOUNDATIONS OF ECONOMIC ANALYSIS (1947); Hendrik S. Houthakker, Revealed Preference and the Utility Function, 17 Economica 159 (1950); and IAN LITTLE, A CRITIQUE OF WELFARE ECONOMICS (2 ${ }^{\text {nd }}$ ed. 1957).

${ }^{12}$ For examples of the use of social choice theory, see KENNETH J. ARrow, SOCIAL CHOICE AND INDIVIDUAL VAlues, (2ND ED. 1963); and Kenneth J. Arrow, Values and Collective Decision Making, in: PhILOSOPHY, Politics AND SOCIETY (PETER LASLETT AND W. G. RUNCIMAN EDS., 1967).

${ }^{13}$ For examples of the use of experimental economics and psychology, see Jennifer Arlen, The Future of Behavioral Economic Analysis of Law, 51 Vand. L. Rev. 1765 (1998); and Richard A. Posner, Rational Choice, Behavior Economic, and the Law, 50 Stan. L. Rev. 1551 (1998).

${ }^{14}$ For an example of the use of majoritarian default theory, see Ian Ayres and Robert Gertner, Filling Gaps in Incomplete Contracts: An Economist Theory of Default Rules, 99 Yale L. J. 87 (1989). 
reifications, which are justified by an abstracted, formalized modeling process that imposes claims that cannot be verified. It seems obvious that such reifications must be treated with suspicion, especially when such constructed interests are connected to a normative project, which waves the battle flag for either shareholders, managers or directors as it surges into the regulatory landscape of the post-privatization era. Again, such atomized interest-based claims must always be treated as politically contentious, but all too often the opposite occurs, as such propositions are treated as matters of scientific fact.

So what to do? One suggestion is to start to trace what has been argued in the literature to date. For this reason, Part II will briefly refresh the reader's memory by presenting one narrative of how the American corporate governance debate emerged. Part III will provide a concise chapterby-chapter roadmap for Bainbridge's arguments in The New Corporate Governance. Part VI will take a closer look at what Bainbridge tacitly suggests is the genius of Delaware's corporate law by mapping the debates which have raged over managerialism, state competition, and Delaware: America's regulatory laboratory for de facto "national" corporate law. This will provide a snapshot of the context from which The New Corporate Governance has emerged. Part V will conclude the review article by offering some reflections on what place the book holds within today's American corporate governance debate.

\section{THE ORIGINS OF CORPORATE GOVERNANCE IN THE AMERICAN CONTEXT}

\section{A. From Personal Capitalism to Managerial Capitalism and Beyond}

In the second half of the nineteenth century, the way that the corporation was organized experienced a radical change, which corresponded with the shift "from traditional, personal capitalism toward managerial capitalism" ${ }^{15}$ in American society. ${ }^{16}$ This shift can be marked by the advent of three innovations: the railway, the telegraph and a reliable supply of energy. Prior to this, a production system was small enough to be managed and supervised by its owner(s) with the help of possibly one or two hired managers, in most cases. ${ }^{17}$ Some who may hold

\footnotetext{
${ }^{15}$ Alfred D. Chandler, Jr., The United States: Seedbed of Managerial Capitalism, in: MANAGerial Hierarchies: Comparative Perspectives on the Rise of the Modern Industrial Enterprise (Alfred D. Chandler, JR. AND HERMAIN DAEMS EDS., 1980) [hereinafter Chandler, Managerial Capitalism].

${ }^{16}$ For an appreciation between a shift in institutional structure like a model of capitalism and the corresponding shifts in an organization within that institutional structure, see DoUGlass NORTH, INSTITUTIONS, INSTITUTIONAL Change And EConomic Performance (1990).

${ }^{17}$ Chandler, Managerial Capitalism, supra note 15, at 14.
} 
different views of the history of corporateness may wonder whether or not this Chandlerian view of capitalism and the corporation is too limited. ${ }^{18} \mathrm{Be}$ that as it may, it is submitted that the narrative of the shift from personal capitalism to managerial capitalism captures the way most observers in American corporate governance circles understand the transformation of American capitalism at the dawn of the twentieth century.

By the 1850s, innovations in transportation and communication flourished, resulting in the rise of multiunit enterprises. Commodity dealers and wholesalers squeezed out established merchants that could not adapt to technological change. ${ }^{19}$ These new players provided the opportunity for a constant flow of raw materials for manufacturing. They also offered more efficient channels to funnel finished products to consumers. Innovation had offered American business the opportunity to exploit the power of mass distribution; all that was needed now was a continuous, cheap and easily accessible supply of energy to feed the belly of mass production.

By the 1860s, the American oil boom was in full swing, ${ }^{20}$ and oil became very cheap and very plentiful. Furthermore, oil was much easier to handle and transport than coal, radically improving conditions for the development of uninterrupted mass production. By late 1870s, continuous process factories started operating. ${ }^{21}$ As businessmen felt the pinch, they rapidly rationalized their operations and moved toward economies of scale. Suddenly the modern corporation was born as all aspects of mass production and mass distribution became organized under single hierarchical operations.

The modern corporation came at a cost to traditional ownership structures. First, owners had to open their proprietary monopolies by selling shares of their ownership in order to finance the expansion and rationalization of operations. This eventually had the effect of dispersing ownership power. Second, owners also surrendered control of these new organizations to salaried managers with the professional training necessary to adequately supervise the operation of these new vast and complex systems of production and distribution. This eventually had the effect of separating managerial power from the now more dispersed ownership structure. Thus, the shadow of ownership and control appeared as the modern corporation emerged in the era of managerial capitalism.

To fund the expansion of their operations, many businessmen used the sophisticated financial

\footnotetext{
${ }^{18}$ More recently, see Leslie Hannah, The Divorce of Ownership and Control from 1900: Re-calibrating Imagined Global Historical Trends, 49 Bus. History 404, 425 (2007). For another example of a rival history of corporateness, which notes a number of organizations that were too vast and complex to fit neatly within Chandler, Managerial Capitalism's narrative of the shift from personal to managerial capitalism, see Paul G. Mahoney, Contract of Concession? An Essay on The History of Corporate Law, 37 Ga. L. Rev. 873, 878-886 (2000).

${ }^{19}$ The transformation of these transportation and communications systems was so rapid that, in many cases, even these middlemen were in decline by the 1880 's, when wholesalers began to give way to the new mass retailers like department stores and mail-order houses. See Chandler, Managerial Capitalism, supra note 15, at 20.

${ }^{20}$ Brian Black, Petrolia: The Landscape of America's First Oil Boom 31-32 (2000).

${ }^{21}$ Chandler, Managerial Capitalism, supra note 15, at 22.
} 
markets in New York, which had matured after the War of 1812, when it was used to raise capital for building canals, turnpikes and railways. ${ }^{22}$ These dealings caused radical shifts in the corporate form. Corporate financing and investing in stocks became fashionable and expanded through the Eastern middle class of America. This accelerated the change in corporate ownership structure, as average Americans, who had little or no understanding of the businesses in which they were investing, were now infiltrating the shareholder class, which was once exclusively filled with business-smart entrepreneurs, who traditionally kept a close eye on corporate operations. The legal community became concerned with this shift in ownership structures, which had the potential of allowing those uneducated in business practice too much voice in the management of the evermore-complex American economy. Thus, a consensus emerged that professional managers were in the best position to exercise corporate discretion.

As time passed so did day-to-day corporate power pass from investors and founders to professional managers. By 1919, the majority of those companies founded prior to 1917 were under the control of managers - not owners. ${ }^{23}$ One reason for this was that the founding owners needed evermore-extensive training and experience to adequately manage these increasingly complex organizations and many such investors, who received large incomes from their ownership regardless, did not wish to dedicate their lives to managing these economic behemoths. $^{24}$ This state of affairs suited those legal observers hoping for the professional management of the economy. By the 1920 s, the shift of opinion toward endorsing managerialism was being evermore loudly endorsed by the legal community. ${ }^{25}$

At the close of the nineteenth century, managerialism was the dominant normative presumption for good corporate governance. This was due to the fact that with the growing popularity of investing within the middle class, the makeup of shareholders shifted dramatically. With this shift, the legal community also changed their opinion of what the role of the shareholder should be within the corporation to either: 1) fit this evolution, or more cynically 2) shield corporate decision-making from ignorant opinions of the new middle class shareholder.

\footnotetext{
${ }^{22}$ Charles R. Geisst, Wall Street: A History. From Its Beginnings to the Fall of Enron 28 (2004).

${ }^{23}$ Chandler, Managerial Capitalism, supra note 15, at 30-31.

${ }^{24} I d$. at 31 .

${ }^{25}$ Early in the twentieth century, the pendulum began to swing toward managerialism. Howard Spellman explained that because of the diversification of the purchase and sale of corporate securities in the twentieth century there evolved a tendency in law "toward an emphasis of the directors' absolutism in the management of the affairs of large corporations; the board of director had achieved a super-control of corporate management and of the corporation's legal relations". He added later in his book, "The powers of the board of directors ... are identical with the powers of the corporation." See Howard H. Spellman, A Treatise on the Principles of Law GOVERNING CORPORATE DireCtORS (1931) at 4-5 \& 237. For judicial treatment of the issue that supports Spellman's observations, see People ex rel. Manice v. Powell, 201 N.Y. 194 at 200 (1911); and Manson v. Curtis, 223 N.Y. 313 at 322, 199 N.E. 558 at 562 (1918).
} 


\section{B. Berle's Protest Against Managerialism}

By the 1920s, Adolf A. Berle was alarmed by the shift away from shareholder primacy toward managerialism, having viewed the transfer of greater corporate power to the average middle and working class man as a positive development in American society, which possessed great democratic potential. ${ }^{26}$ In his more personal and candid writings, he reveals another underlying and inseparable motivation for promoting shareholder primacy. ${ }^{27} \mathrm{He}$ was worried that the legal community, by overreacting to the change in ownership from a sophisticated business class to the middle class, was making a grave mistake. Placing greater discretion into the hands of managers without safeguards was merely stoking the fire of a far more serious problem facing America, which was the potential fallout from, as Berle put it: "the freewheeling manner in which [managers] had dealt with the stock and other interests of their companies up to that time". ${ }^{28}$ Thus, he regarded the trends toward managerialism as a dangerous mistake, which could destabilize American society.

As a result, Berle started to construct arguments based on property rights, which justified shareholder authority over corporate management. He published four articles between 1923 and $1926,{ }^{29}$ building a shareholder primacy argument prior to his most famous position on

\footnotetext{
${ }^{26}$ Adolf A. Berle, Jr., How Labor Could Control, 28 The New Republic 37 (1921) [hereinafter Berle, Labor]. Also See Jordan A. Schwartz, "Liberal: Adolf A. Berle and the vision of an American era" (1987), 66 [hereinafter Schwartz, Berle].

${ }^{27} I d$. at 66 .

${ }^{28}$ Entry from Berle's personal diary on August 25, 1932, in: NAVIgATING THE RAPIDS 1918-1971: From THE Papers of Adolf A. Berle 19 (Beatrice Bishop Berle and Travis Beal Jacobs eds., 1973) [hereinafter Berle, Papers of Berle].

${ }^{29}$ In his first article in the series, Berle noted the trend in corporate law to grant directors broad power to distribute dividends could violate shareholders' rights, which necessitates a more narrow interpretation of managerial power. Although the discretion to withhold dividends to bolster the capital of the corporation was absolute and equitable, if the corporation used the dividends of non-cumulative preferred stockholders, these dividends were not lost to this class, but must be recorded and returned to them before common shareholders could receive dividends. See Adolf A. Berle, Jr., Non-cumulative Preferred Stocks, 23 Colum. L. Rev. 358 (1923). In his next article, pre-existing shareholders' rights were challenged by the managerial discretion to issue non-par stocks, which was significant, because existing contractual arrangements might not have foreseen this innovation at the time. Berle acknowledged that such unforeseen evolutions in corporate law created a crisis, since they potentially freed management to act without regard for the interests of shareholders. To remedy this failure of the contract, Berle asserted that the rights of shareholders created an obligation for management (like agents) to manage the corporation in shareholders' best interests, regardless of whether this obligation was explicitly contractual. Berle appeared confident that courts would recognize that shareholders could rely on equity to protect their rights. See Adolf A. Berle, Jr., Problems of Non-Par Stocks, 25 Colum. L. Rev. 43 (1925). After this, Berle explored how management allocated dividends (and losses) between share classes of the corporation. Once again, he employed the theory of the corporation as the private property of shareholders. He asserted even after management allocated initial preferred dividends in accordance with explicit contractual requirements, the remaining surplus, if it was to be allocated as dividends, was subject to an equitable distribution. This illustrated how principles of equity, beyond contract, provided a rationale for ordering how dividends were to be portioned amongst shareholders, which protected weaker shareholders from the influence of powerful ones. See Adolf A. Berle, Jr., Participating Preferred Stock, 26 Colum. L. Rev. 303 (1926). And finally, in his 1926 Harvard Law Review article, Berle furthered this argument by demonstrating that equity compensated
} 
shareholder primacy: "Corporate Powers as Power in Trust" ${ }^{30}$. Each followed a similar logic: the corporation was the private property of its shareholders, and since managers were the agents of these owners, they owed a duty of care to them, which was captured in law by contract, and as Berle noted in the later works, by equity as well. Each article noted how corporate management was granted discretion over a particular aspect of the function of the corporation, which prima facie appeared quite broad. However, Berle then reminded his reader that the particular managerial discretion in question was held in check by shareholder rights, and thus the range of managerial choice that actually existed was more restricted than an observer might have assumed.

When these articles are read with Berle's biographical context in mind, ${ }^{31}$ it becomes clear that his prime concern was controlling the self-interested and irresponsible actions of management, who controlled one of the most important political actors within American society: the corporation. ${ }^{32}$ More importantly, Berle's more candid writings indicate that he wanted the corporation to help American society avoid the internal strife that Europe appeared doomed to suffer. ${ }^{33}$ Accordingly, his objective was to help empower shareholders (which he saw as evermore representing the middle and working classes) to make corporate managers firmly accountable to their control: in other words, the wider polity. He envisioned the distribution of corporate ownership through the middle and working classes as a mechanism to place the power of economic concentration under a form of democratic control through shareholder power. In fact, Berle had the bold ambition of becoming the prophet of the shareholding class, or as he so modestly put it, "the American Karl Marx". 34

What is missed by most modern commentators on Berle's work is that he only intended for shareholder primacy to be an interim measure until a more adequate sociological clarification of the corporate property evolution was offered then accepted by the legal and business communities. ${ }^{35}$ Put differently, Berle was advocating the shareholder primacy position until a

for de facto imbalance of power between shareholders, arguing that the law would ensure that management treated all shareholders evenhandedly, guaranteeing that the interests of ownership were not undermined. See Adolf A. Berle, Jr., Non-Voting Stock and Bankers Control, 39 Harv. L. Rev. 673 (1926).

${ }^{30}$ Adolf A. Berle, Jr., Corporate Powers as Power in Trust, 44 Harv. L. Rev. 1049 (1931) [hereinafter Berle, Corporate Powers].

${ }^{31}$ For detailed contextualization of Berle's biographical information with his academic writing during this time period, See Stewart, Role of Law, supra note 2, at Chapter 4.

${ }^{32}$ Entry from Berle's personal diary on August 25, 1932, in: Berle, Papers of Berle, supra note 28, at 19.

${ }^{33}$ Schwartz, Berle, supra note 26, at 66.

${ }^{34}$ Berle exclaimed to his wife: "that his real ambition in life is to be the American Karl Marx - a social prophet", See Schwartz, Berle, supra note 26, at 62. Also See Thomas K. McCraw, Berle and Means, 18 Rev. Am. His. 578, 579 (1990).

${ }^{35}$ For arguments explaining the important of the fact that Corporate Powers as Power in Trust is an exact reproduction of Berle's initial essay of the Berle-Dodd debate except Berle removed from the article his candid admission that his arguments were constructed "with full realization of the possibility that private property may one day cease to be the basic concept in terms of which the courts handle problems of large scale enterprise", See 
satisfactory solution to the problems of corporate property could be established. The challenge to redefine corporate property never sparked the sort of evolution in thought that Berle had imagined, although this was where the seeds of planners, or state, corporatism emerged in the context of the New Deal. ${ }^{36}$ This corporatism was what Berle advocate for at the end of The Modern Corporation and Private Property as well as within the Roosevelt Administration. ${ }^{37}$

Dodd reacted to "Corporate Powers as Power in Trust" in his 1932 article, entitled "For Whom Are Corporate Mangers Trustees?". ${ }^{38}$ This article can be described as a wildly romantic reversion of managerialism that throws caution to the wind. Dodd's argument contradicted his own best judgment (as established by the archive of his work). ${ }^{39}$ This is why he later admitted that this argument was "rash" and riddled with "legal difficulties". ${ }^{40}$ Thus, this article should be regarded

Stewart, Role of Law, supra note 2, at Chapter 4. For quotation within this footnote, See ADOLF A. BERLE, JR. AND Gardiner C. Means, The Modern Corporation and Private Property 219-220 (rev. ed. 1968, $1^{\text {st }}$ ed. 1932) [hereinafter Berle and Means].

${ }^{36}$ Bratton \& Wachter, Corporatist Origins, supra note 1, at $17 \& 27$ (describing corporatism as a cooperative relationship between private groups and also between government and those groups that communicate in order to establish "public interest" on an issue, and then adopt, adapt and coordinate policies accordingly in order to achieve the agreed upon "public interest" within society). Also see Ellis W. HAWley, The New Deal AND The Problem OF MONOPOLY 36-43 (1966) (categorizing two types of corporatism: 1) "planners" corporatism that advocates for the government to take the lead role in this process, and 2) "business commonwealth" corporatism that advocates for industrialists to take the lead role).

${ }^{37}$ Berle and Means, supra note 35, at 309-316. Also see Stewart, Role of Law, supra note 2, at Chapter 4.

${ }^{38}$ E. Merrick Dodd, Jr., For Whom Are Corporate Mangers Trustees?, 45 Harv. L. Rev. 1145 (1932) [hereinafter Dodd, For Whom Are].

${ }^{39}$ A review of examples that support this claim from the body of Dodd's work follows. In a two-part series, Dodd explored the limits of management power to alter corporate charters. See E. Merrick Dodd, Jr., Dissenting Stockholders and Amendments to Corporate Charters, 75 U. Pa. L. Rev. 585 (1927); and E. Merrick Dodd, Jr., Dissenting Stockholders and Amendments to Corporate Charters (continued), 75 U. Pa. L. Rev. 723 (1927). In another article, Dodd highlighted from the case law that a reorganization plan of an insolvent corporation could not properly be confirmed if the plan preserves an interest to the shareholders, unless the shareholders make a new contribution to the new company and unless no creditor appears to opposition to it. See E. Merrick Dodd, Jr., The Los Angeles Lumber Products Company Case and its Implications, 53 Harv. L. Rev. 713 (1940). In another particularly relevant article, Dodd traced the radical change in the impact of the fiduciary principle from small-scale to large-scale capitalism. See E. Merrick Dodd, Jr., Modern Corporation, Private Property, and Recent Federal Legislation, 54 Harv. L. Rev. 917 (1941). In another, Dodd argued that corporate management's ability to purchase and redeem its own company shares ought to be brought within the fiduciary obligation. See E. Merrick Dodd, Jr., Purchase and Redemption by a Corporation of Its Own Shares: The Substantive Law, 89 U. Pa. L. Rev. 697 (1941). Dodd again argued that corporate management ought to act in light of their fiduciary obligation for the benefit of security holders in relation to their interest. See E. Merrick Dodd, Jr., Fair and Equitable Recapitalizations, 55 Harv. L. Rev. 780 (1942). In the following article, he showed great concern for the fiduciary principles, especially in relation to the obligation of majority shareholders to minority shareholders or to a particular class of shares. See E. Merrick Dodd, Jr., Liability of a Holding Company for Obtaining for Itself Property Needed by a Subsidiary - The Blaustein Case, 58 Harv. L. Rev. 125 (1944). For supporting commentary, See Ralph J. Baker, Edwin Merrick Dodd, 65 Harv. L. Rev. 389 (1952), 390; and Zechariah Chafee, Jr., Edwin Merrick Dodd, 65 Harv. L. Rev. 379 (1952), 382.

${ }^{40}$ E. Merrick Dodd, Book Reviews, 9 U. Chi. L. Rev. 538, 546 (1942) 
more as a consequence of Berle's extremism than a reflection of Dodd's better judgment. Dodd intended to petition those potentially lured by Berle's extremism to keep an open-mind and not to close the door on the potential for enlightened managerial behavior. And yet, Dodd was overzealous in making this point, crossing the line between suggesting the potential of managerialism and fully advocating for it in a rash and reactionary manner. Therefore, to understand Dodd's position within the corporate governance debate, one must emphasize the contradictory nature of Dodd's other anti-managerialist writings on the topic, before and after For Whom Are Corporate Managers Trustees?.

In reply to Dodd, Berle argued clearly that shareholders' fiduciary controls over management could not be abandoned by lawyers until a new order emerged, noting that "legal technique [did] not contemplate intervening periods of chaos", but would only respond to new outcomes or theories as they were established. ${ }^{41}$ Berle's argument in the 1932 article mirrored his arguments from chapter seven of book two of The Modern Corporation and Private Property ${ }^{42}$ where he argued that social science needed to better guide the legal understanding of the evolving corporate form, and that only after this was done could the law play a role in the emerging new order. ${ }^{43}$ Berle emphasized that lawyers needed new legal tools to bring corporate behavior under greater control. ${ }^{44}$ And until such time, shareholder primacy was the only tool available.

Berle appreciated that social thought in America had to catch up with the reality of the evolution of the modern corporation before progressive managerialism could realistically be advocated in the corporate legal discourse. So, the reason The Modern Corporation and Private Property must be read as advocating shareholder primacy as a solution (not planners corporatism, such as was argued at the end of the book) is because, when the book was published, sociology had not worked out an approach to understanding the corporation, which would facilitate the policy and legal developments necessary to advocate progressive managerialism with any degree of success. In fact, it still hasn't.

To be clear, Berle argued in 1931 that "all powers granted to a corporation ... [were] ... at all times exercisable only for the ratable benefits of all the shareholders as their interest appears" 45 without qualification. For Berle, the average shareholders were middle and working class Americans, and the corporation was the key to their economic emancipation. He believed that the increasing dispersion of ownership and economic power throughout American society through shareholding was eventually going to help the average American achieve a more satisfactory

\footnotetext{
${ }^{41}$ Adolf A. Berle, Jr., For Whom Corporate Managers are Trustees: A Note, 45 Harv. L. Rev. 1371, 1365 (1932) [hereinafter Berle, For Whom].

${ }^{42}$ See Berle and Means, supra note 35, at 219-220.

${ }^{43}$ Berle, For Whom, supra note 41, at 1371-1372.

${ }^{44}$ Id. at 1371-1372.

${ }^{45}$ Berle, Corporate Powers, supra note 30, at 1049; and Berle and Means, supra note 35 at 220.
} 
level of equity within their society. ${ }^{46}$ Dodd regarded shareholders as sophisticated private actors with interests that were rarely aligned with public interest, and as a consequence, also regarded Berle as a dangerous conservative, which inspired his reply.

\section{Shareholder Primacy Reconceived: The Seeds of Corporate CONTRACTARIANISM}

Fast-forwarding through the New Deal, the war years and post-war reconstruction, by the 1960s, Henry Manne emerged as an important voice in the corporate governance debate. Manne was a precursor to the legal contractarian position. ${ }^{47}$ One of his most significant achievements was that he "flipped" ${ }^{48}$ the shareholder primacy argument by redefining the interests of shareholders. ${ }^{49}$ For Manne, shareholders were not the middle and working class Everyman but rather a personification of "the market", which defined shareholders collectively as efficient and thus sophisticated investors (much like Dodd regarded them, but where Manne saw praiseworthiness, Dodd saw grounds for suspicion). In a stroke of tactical genius, Manne gutted the substance of Berle's shareholder primacy argument, and then used Berle's own arguments to undermine Berle's position. ${ }^{50}$ Although Dodd did not live to read Manne's thought, his acolytes were insensitive to the significance of this shift. The work of Manne, when considered with the earlier thought of Ronald Coase,${ }^{51}$ marked the start of the shift that in time would prove to be one of the

\footnotetext{
${ }^{46}$ Schwartz, Berle, supra note 26, at 66. But also, See Berle, Labor, supra note 26; Berle, Corporate Powers, id.; and Berle, For Whom, supra note 4.

${ }^{47}$ For the development of the "nexus of contracts" metaphor, see Lewis A. Kornhauser, The Nexus of Contracts Approach to Corporations: A comment on Easterbrook and Fischel, 89 Colum. L. Rev. 1449 (1989) [hereinafter Kornhauser, Easterbrook and Fischel]; Melvin A. Eisenberg, The Conception that the Corporation is a Nexus of Contracts and the Dual Nature of the Firm, 24 J. Corp. L. 819 (1999) [hereinafter Eisenberg, Dual Nature of the Firm]; and William W. Bratton, Jr., The "Nexus of Contract" Corporate: A Critical a Appraisal, 74 Cornell L. Rev. 407 (1989) [hereinafter Bratton, A Critical a Appraisal].

${ }^{48}$ For more on how arguments can be flipped, see DUNCAN KENNEDY, A CRITIQUE OF ADJUDICATION: Fin DE SIÈCLE (1997); and also See Kerry Rittich, Functionalism and Formalism: Their Latest Incarnations in Contemporary Development and Governance Debates, 55 U. of T. 853 (2005).

${ }^{49}$ Henry G. Manne, Accounting for Share Issues under Modern Corporation Laws, 54 Nw. U. L. Rev. 285 (1959); Henry G. Manne, Current Views on the Modern Corporation, 38 U. Det. L. J. 559 (1961); Henry G. Manne, Corporate Responsibility, Business Motivation, and Reality, 343 Annals 55 (1962); Henry G. Manne, The 'Higher Criticism' of the Modern Corporation, 62 Colum. L. Rev. 399 (1962) [hereinafter Manne, Higher Criticism]; Henry G. Manne, Some Theoretical Aspects of Share Voting-An Essay in Honor of Adolf A. Berle, 64 Colum. L. Rev. 1427 (1964) [hereinafter Manne, in Honor of Berle]; and Henry G. Manne, Mergers and the Market for Corporate Control, 73 J. Pol. Econ. 110 (1965).

${ }^{50}$ For Manne's attack on Berle's writing, see Manne, Higher Criticism, id.; and also less directly, see Manne, in Honor of Berle, id..

${ }^{51}$ Ronald Coase, The Nature of the Firm, 4(16) Economica 386 (1937).
} 
defining moments in the turn from the entity model of the corporation ${ }^{52}$ toward the contractarian one $^{53}$. A shift more recently described as a shift from the firm as a political actor toward the firm as a market actor, ${ }^{54}$ one that sparked a managerial revolution in which American managers started to place less emphasis upon balancing constituent interests of the firm and much more emphasis upon maximizing shareholder value.

That said, Berle was obviously sensitive to this shift in the use of his argument, but since it was the golden age for Keynesian economics and Welfare statism, he underestimated the power of Manne's position, dismissing this neoclassical application of shareholder primacy as anachronistic. ${ }^{55}$ But by the late 1970 s, when the retooling of Bretton Woods started to eviscerate National Keynesianism, the legal contractarian position started to gain more political traction. The contractarians used their new political influence to champion the interests of shareholders. Following Manne's lead, they defined shareholders as representing a much narrower range of interests than Berle had originally conceived. Accordingly, they argued that corporate governance was purely a private matter, and that the state should not impose extra-contractual burdens on market actors, since the market could discipline their behavior more effectively than political intervention ever could. ${ }^{56}$ From this perspective, the creation of a wealthier society was

${ }^{52}$ For discussion of the theory when it was being endorsed, see F.W. Maitland, Moral Personality and Legal Personality, in: The Collected. Papers of Frederic William Maitland Vol. Ill (H. A. L. FisheR, ED., 1911); Dodd, For Whom Are, supra note 38; Berle and Means, supra note 35; AdOLF A. BERLE, JR., THE $20^{\mathrm{TH}}$ CENTURY CApitalist Revolution (1954) [hereinafter Berle, Capitalist Revolution]. For further historical detail, see Morton J. Horwitz, Santa Clara Revisited: The Development of Corporate Theory, 88 W. Va. L. Rev. 173 (1985) [hereinafter Horwitz, Santa Clara Revisited]; Mark M. Hager, Bodies Politic: The Progressive History of Organizational "Real Entity" Theory, 50 U. Pitt. L. Rev. 575 (1989); William W. Bratton, Jr., The New Economic Theory of the Firm: Critical Perspectives from History, 41 Stan. L. Rev. 1471 (1989); and David Millon, Theories of the Corporation, 1990 Duke L. J. 201 (1990) [hereinafter Millon, Theories].

${ }^{53}$ For an endorsement of this evolution, see Kornhauser, Easterbrook and Fischel, supra note 47. For a methodical scrutinizing, see Bratton, A Critical a Appraisal, supra note 47; and Eisenberg, Dual Nature of the Firm, supra note 47. The synthesis of these ideas was best packaged and elaborated upon by Oliver E. Williamson. Williamson takes seriously the idea that transaction cost is an important, but not the sole, lens to look through in order to understand the corporation. He suggests that many who would argue that the corporation pursues antisocial objectives, do not understand the main purposes of the corporation and thus help in the creation ill-conceived public policy to adversely address problems, which are too complex for such blunt policies to adequately tackle. Williamson attempts to provide a coherent view of the modern corporation as a cite of production, introducing a methodology of studying firms and markets as alternative governance models, which can be compared by studying their institutional structure, in order to appreciate organizational innovations that reduce transaction costs and helps markets be more efficient not less efficient. See Oliver E. Williamson, The Modern Corporation, 19 J. Econ. Literature 1537 (1981). Also see Oliver E. Williamson, Corporate Control and the Theory of the Firm, in: ECONOMIC POLICY AND THE Regulation of Corporate Securities (Henry G. Manne, ed., 1969), 281 [hereinafter Williamson, Corporate Control].

${ }^{54}$ See Zumbansen, Evolution of the Corporation, supra note 2.

55 Adolf A. Berle, Modern Functions of The Corporate System, 62 Colum. L. Rev. 433 (1962) [hereinafter Berle, The Corporate System].

${ }^{56}$ See Frank H. Easterbrook and Daniel R. Fischel, The Economic Structure of Corporate LAw 6-7, $30-$ 31, 37-29, 170-171 (1991). But also see Michael C. Jensen and William H. Meckling, Theory of the Firm: Managerial Behavior Agency Costs and Ownership Structure, 3 J. of Fin. Econ. 305, 355 (1976). 
how the corporation would help advance public interest. With the acceptance of this suggestion, the era of the primacy of the market and global financialization took off.

If the Doddish managerialists would have been properly focused on the problem of the atomization of corporate governance actors (instead of reacting to shareholder primacy), they would have been alarmed at how easily such atomized interest-based politics were flipped from Berle's position to Manne's position. The reason that this was so easy was that the underlying assignment of interests to a particular constituent group is never verifiable. Managerialists were caught flatfooted. As a result, most Doddish corporate responsibility projects have remained misdirected to this day, aligning themselves with managers by assuming that they will be more responsible than shareholders for looking after the best interests of the corporation. Such uncritical assumptions have dangerously atrophied the potential of developing more significant normative options for corporate governance. ${ }^{57}$

Admittedly, the last section was a speedy slice through the history of American corporate governance and it misses many steps, especially from the late seventies forward, but at least this refresher can stand as a rough sketch of a historical framework into which Bainbridge's The New Corporate Governance can be placed. After recapitulating the arguments from Bainbridge's new book in Part III, Part IV will elaborate on the more recent history of the corporate governance debate, focusing on those features of the debate that are closely connected to Bainbridge's arguments from The New Corporate Governance.

\section{A SUMMARY OF THE NEW CORPORATE GOVERNANCE}

\section{A. INTRODUCTION}

In his introduction, Bainbridge lays the groundwork for his arguments. He maintains that the boards of directors for America's large public corporations are becoming more than mere rubber stamps for CEOs and other top executives. If Bainbridge's observation is correct, then directors are finally about to take the mantle of power that corporate law has for so long reserved for them. However, up to this time, directors have rarely been separated from "managers" in the managerialist literature, and for good reason, since directors are rarely distinguishable from corporate executives in their decision-making choices. ${ }^{58}$ For this reason, beneath Bainbridge's

\footnotetext{
${ }^{57}$ William W. Bratton, Welfare, Dialectic, and Mediation in Corporate Law, 2 Berkeley Bus. L. J. 59 (2005), 73-74 [hereinafter Bratton, Welfare, Dialectic, and Mediation].

${ }^{58}$ For instance, read The Economists claim that directors are the lapdogs of managers on the critical issue of executive compensation: “... many bosses in other industries are overpaid because weak boards have allowed them to dictate the terms of their compensation. As a result, pay bears little relationship to performance and tends to rise inexorably. A chief critic of the supposed corporate gravy-train is Warren Buffett. At the annual meeting of his holding company, Berkshire Hathaway, on May 2nd the legendary investor railed against a system that lets chief
} 
description of Delaware's status quo lays a contentious theory that a functional revolution is occurring in American corporate governance.

If Bainbridge is correct, his book will historically mark a shift in governance away from Chandler's model of managerialism to a board-centered fiat model; a model he calls director primacy. Bainbridge promises his book to be an interdisciplinary analysis of this emerging evolution of the board of directors, using doctrinal legal analysis, behavioral economic insights, the work of new institutional economics on organizational structure, and management studies of corporate governance. At the end of his introduction, he offers a concise road map to the next five chapters that make up the remainder of his book for anyone who needs further verification on whether it is relevant to their interests.

\section{B. CHAPTER ONE}

In Chapter One, Bainbridge explains the key elements of his director primacy theory. He strongly endorses Delaware's off-the-rack default statutory model of corporate governance, which advocates the protection of the board's authority against direct shareholder influence in day-to-day decision-making. In fact, it has been suggested that he advocates a more pro-board position than Delaware dares. ${ }^{59}$

He describes how Delaware's corporate law protects the primacy of the directors to govern the corporation, asserting that this doctrinal position sits well with prevailing corporate theory. In particular, he contends that Delaware's director primacy fits nicely with the contractarian concept of the firm. Bainbridge explains that decision-making by fiat, which the board represents, is where the nexus of contracts meets and where the decision-making power about how to manage this nexus is most efficiently allocated.

Bainbridge explains that there will always be a need to balance the authority and accountability of directors, but that the complexities and demands of managing this nexus suggest that careful consideration must be taken before limiting the authority of the board. He warns that by limiting board authority, there is a great danger that the corporation's ability to be innovative will be also stifled. He offers a number of arguments for broad directorial discretion, ${ }^{60}$ possibly providing his best defense of Delaware's allocation of authority to directors, which may be at the expense of

executives choose the members of remuneration committees. This, he claimed, allows them to select compliant directors prepared to wave through pay proposals. "These people aren't looking for Dobermans," he complained. "They're looking for cocker spaniels." See Attacking the corporate gravy train, The Economist, May $28^{\text {th }}, 2009$.

${ }^{59}$ For more detail on this argument, see Brett H. McDonnell, Professor Bainbridge and the Arrowian Moment: A Review of The New Corporate Governance in Theory and Practice, 34 Del. J. Corp. L. 139 (2009).

${ }^{60}$ For more details read Bainbridge's relevant arguments, see Bainbridge, Corporate Governance, supra note 3, at 45-75. 
greater shareholder empowerment. However, if what he contends is true, this broad discretion is ultimately in their best interest.

Although Bainbridge argues that corporate boards do (and should) have final authority over decision-making (which traditionally would signal managerialism), his arguments also align with the shareholder primacy position, arguing that such decision-making authority must be for the sole benefit of shareholders (which is classically anti-managerialist). He justifies this position normatively by using the dubious majoritarian default model, which suggests that the shareholder wealth maximization norm is what all stakeholders of the firm ultimately want, since default rules that pander to management (unlike Delaware's in his estimation) are inefficient: increasing the cost of capital, creating greater vulnerability to hostile takeover and negatively affecting the overall health of the corporation. The distinction that Bainbridge makes between director primacy and shareholder primacy is that the advocates of shareholder primacy extend their backing of shareholder power beyond the shareholder wealth maximization norm, pushing for shareholders to have more direct control over the day-to-day affairs of the firm, while director primacy only advocates actualizing the shareholder wealth maximization norm.

Putting the collective action problems of a widely dispersed shareholder class to one side, he suggests that directors, who are motivated primarily by the shareholder wealth maximization norm, will more vigilantly care for the firm's wellbeing for the benefit of shareholders than direct shareholder empowerment could. ${ }^{61}$ One reason for this is because often times shareholders can exit the firm with ease and such unattached shareholder influence can focus the firm on short-term, ill informed, and/or self-serving goals that can possibility corrupt prudent corporate strategy over the long-term. Another reason for endorsing director primacy is that such direct shareholder empowerment would serve only to endorse the special interests of those who have power within the shareholder class: institutional investors. Thus, further empowering shareholders only advantages special interests within the shareholder class (institutional investors) and not the class as a whole.

\section{Chapter Two}

In Chapter Two, Bainbridge justifies why authority ought to rest with the board of directors within the corporate governance structure. He argues that a governance group (that acts collegially) is superior to a single autocrat at the apex of the corporate governance hierarchy. In making this argument, he offers evidence from the behavioral economics literature, which explains why group decision-making is of higher quality than individual decision-making. ${ }^{62}$ This leads him to conclude that corporate boards are more effective at monitoring corporate governance than a single autocrat, and thus the fiat model is generally the best option.

\footnotetext{
${ }^{61} I d$. at 55-57.

${ }^{62}$ For more details read Bainbridge's relevant arguments, see id. at 82-104.
} 
The main problem with the fiat model is: who watches the watchers? In other words, who keeps the board of directors from being poisoned by groupthink and/or other forms of collective action failure? And who keeps the board of directors from social loafing and/or other serious opportunistic behavior? Bainbridge's answer is the board itself. The arguments justifying this answer are at best hopeful. The optimism of his answer may make some hardened antimanagerialists smile cruelly at the lack of realism that one must embrace to whole-heartedly be at ease with the potential of directors self-monitoring.

To be fair, this is a serious problem with no easy answer and at least Bainbridge deals with it head on. Ultimately, the arguments are sounder in regards to avoiding collective action failure than they are regarding avoiding opportunistic behavior. Albeit, the group dynamic makes opportunism less attractive for one individual within the group than it would for an all-powerful autocrat with no equals. That said, the suggestion that social norms (like reputational cost and the virtues of the communal life within the womb of the boardroom) will prevent the board from benefiting from opportunities that benefit the board as a whole at the expense of all other constituents of the firm may be too sweet for some intimate observers of director politics to swallow.

\section{ChAPTER THREe}

In Chapter Three, Bainbridge suggests that a key problem for corporate governance is locating the appropriate balance between providing enough authority for the board to govern the firm in an efficient manner, while not providing so much discretion that authority becomes unreviewable, uncorrectable and ultimately unaccountable. Therefore, at one extreme, efficiency demands that board decisions are shielded from shareholders and courts, otherwise optimal risktaking will be discouraged and the internal team governance structure could be seriously compromised by the fear of hindsight review. What about the courts protecting shareholders from extensive director discretion? Bainbridge reasons that shareholders are protected from "optimal" risk-taking by the dual functioning of limited liability and portfolio diversity. ${ }^{63}$

At the other extreme, if directors flagrantly violate their obligation to maximize shareholder wealth, the big stick of accountability must come out as a deterrent of corporate irresponsibility. This is not an easy balance to strike, Bainbridge warns, for judges must be careful, since they are not business experts and hindsight can make decision-making look more irresponsible when the consequences of those decisions are known to have been negative.

In finding what balance ought to be struck between authority and accountability, Bainbridge sides with the Unocal case, which provides a conservative interpretation of the application of the

\footnotetext{
${ }^{63} I d$. at 115.
} 
business judgment rule. ${ }^{64}$ The Unocal interpretation views the business judgment rule through the lens of the doctrine of abstention. This interpretation suggests that the business judgment rule allows the courts to go no further than to assess whether a board was disinterested and independent in their decision-making process (good faith) and that the decision-making process was reasonable (no gross negligence). ${ }^{65}$ Thus, Bainbridge endorses a presumption in favor of strong judicial deference to board decisions as long as there is some evidence of good faith and competence. He ultimately justifies this position by reasoning that directors cannot be made more accountable without compromising their authority, leading to less than optimal risktaking. ${ }^{66}$

\section{E. CHAPTER Four}

In Chapter Four, Bainbridge makes his argument for the managerial revolution, which he believes to be underway. It is here that he must establish that directors are becoming change agents by: 1) severing their more or less exclusive loyalty to "managers", 2) championing the rights of all shareholders, and 3) forging The New Corporate Governance. It is here that the director primacy either lives by the sword or dies by the sword, for when Bainbridge attacks managerialism as inadequate, he is challenged to establish how the distinction drawn between managerialism and his director primacy is in fact defensible.

Before Bainbridge, most traditional managerialists assumed that their readers understood that directors were included in the use of the term "managers", because no clear distinction between the decision-making outcomes of directors and senior executives was thought to exist. One major reason for this pre-determination was that the CEO was generally the office where actual power consolidated in public corporations. In practice, the CEO had tremendous control over: 1) who would be on the ballot for board elections, and 2) the flow of information from corporate operations to the board. Many times, the CEO was on the board, if not the chairman of the board, making frank discussions about managerial performance during board meetings at best difficult. Thus, the CEO accumulated much power to manage the corporation. So much that if there was one individual that Bainbridge had in mind in his comparison between group decision-making and individual decision-making, the CEO would likely be that individual, because she/he has historically been the corporation's best approximation of the single autocrat at the apex of the corporate governance hierarchy. In fact, it is not always clear how much the influence of the $\mathrm{CEO}$ has changed in the day-to-day function of the corporation.

The biggest test for the canonization of director primacy is whether it is simply a semantic technique to maintain the defense of the professional bureaucracy that runs the corporation or

\footnotetext{
${ }^{64}$ Unocal Corp. v. Mesa Petroleum Co, 493 A. 2d 947 (Del 1985).

${ }^{65}$ For full analysis of the Unocal test, see Bainbridge, Corporate Governance, supra note 3, at 137-140.

${ }^{66} I d$. at 153.
} 
whether the function of the board can be established as changing. If the behavior of "managers" (excluding directors) is what shareholder primacy advocates are really up-in-arms about, and if directors are really the true champions of the whole of the shareholder class, then director primacy might be The Third Way of corporate governance. However, if the distinction between managerialism and director primacy cannot stand the test of the Devil's Advocate, and directors cannot be established to be different than "managers", this theory will fail to be convincing as a new path for corporate governance.

For this reason, the stakes are at their highest in the book when Bainbridge makes his best case for the distinction between directors and managers in the function of the American board of directors post-Enron. Although Bainbridge argues how director empowerment started much earlier than the enactment of Sarbanes-Oxley ${ }^{67}$ and other amendments to the listing requirements of various American stock exchanges, his position is that these legal changes have finally tipped-the-scales as directors now enjoy enough freedom from executive officers to be able to independently exercise authority over the corporation.

Bainbridge does an excellent job of outlining the argument for the shift from managerialism to director primacy, discussing the directors' evolving role from being the rubber stamps of CEOs to potentially having a legitimate monitoring function. He explains how, starting in the 1970s, pressure mounted to improve what was seen at that time as the board's failure to rein in the excesses of executive officers and improve management's performance. ${ }^{68}$ From this arose the recognition of the important role that independent directors could play within the corporation governance structure. Skipping forward, he then explains how post-Enron developments have bolstered a director's ability to police managers for shareholders by: 1) improving best practice norms, 2) strengthening the threats to a director's reputation for turning a blind eye to managers running roughshod over shareholder interests, 3) increasing judicial pressure for better information flow from management to directors, and 4) increasing requirements for more independent directors on boards.

Ultimately, Bainbridge's reader is waiting for him to proclaim at the end of his analysis (with lots of empirical evidence for support) that these changes are creating "strong, active independent directors with little tolerance for negligence or culpable conduct". words, there is little empirical evidence to support them and there is not much of a bang but merely a whimpering suggestion that they "do exist". ${ }^{70}$ In the end, Bainbridge sounds like Dodd, who merely employed optimism for the new generation of managers in his reply to Berle. ${ }^{71}$ They

\footnotetext{
${ }^{67}$ Pub. L. 107-204, 116 Stat. 745, enacted July 30, 2002. Available at GPO: http://www.gpo.gov/fdsys/pkg/PLAW107publ204/content-detail.html.

${ }^{68}$ For instance, see Melvin A. Eisenberg, The Structure of the Corporation (1976).

${ }^{69}$ Bainbridge, Corporate Governance, supra note 3, at 198.

${ }^{70}$ Id. at 198.

${ }^{71}$ Dodd, For Whom Are, supra note 38, at 1146, 1148, 1151-1153, and 1165-1167.
} 
are both very optimistic about the potential of a bureaucratic revolution, which would transform the ruling fiats of the great American corporations into group decision-making centers that would help manage the economy in a manner that is more beneficial to society. ${ }^{72}$ Both arguments are inspiring, but also lack substance, rendering them both no more than corporate futurism.

In the end, Bainbridge makes quite a weak statement, arguing that the "real world practice" of directors is still "supine", but is "closer to the director primacy model than it was in earlier periods". ${ }^{73}$ One must respect Bainbridge's candor on this point, but it does lay bare what might be the dangerously un-secret weakness of the otherwise invulnerable Siegfried-like argument. ${ }^{74}$

\section{F. CHAPTER Five}

When Bainbridge looks to the future of corporate governance in America, he sees two competing models: shareholder primacy and director primacy. He petitions for greater vigilance in the face of today's pressure to extend the shareholder franchise. He notes that although shareholders are the sole beneficiaries of corporate governance and although directors have a duty to enforce shareholder wealth maximization, there is very good reason why shareholder power is so limited. $\mathrm{He}$ argues that shareholder primacy is a flawed account of American corporate governance. And accordingly, in appreciating the reasons for this, the genius and accuracy of director primacy emerges from the cries that proclaim greater shareholder primacy is the enlightened path for corporate governance.

Bainbridge contends that no shareholder empowerment amendments are needed in order to ensure that the American corporate governance model optimizes shareholder protection. He argues that director primacy satisfies this objective by ensuring that corporate governance abides by the shareholder wealth maximization norm. He warns that shareholder primacy urges policymakers to grant shareholders additional powers to exercise direct control over the corporation, but this will prove to be detrimental to the shareholder class as a whole. This is because special interests (institutional investors), which have consolidated power within the shareholder class, will exploit these additional powers at the expense of weaker shareholders.

Within the existing corporate governance order, Bainbridge suggests that shareholders are happy to be rationally apathetic, ${ }^{75}$ because it is easier to exit than it is to fight. He contends that this is

\footnotetext{
${ }^{72}$ Id. at 1148 .

${ }^{73}$ Bainbridge, Corporate Governance, supra note 3, at 200.

${ }^{74}$ For the story of dragon-slayer Siegfried, which inspired Richard Wagner's "Der Ring des Nibelungen". See SoNG of the Nibelungs: A Verse TRANSLATion from the Middle High German Nibelungenlied (Frank Glessner RYDER TRANS., 1962).

${ }^{75}$ Bainbridge, Corporate Governance, supra note 3, at 202.
} 
even true for institutional investors, because of: 1) the costs of monitoring corporate activities and engaging in activism, 2) the frequency of free riding on such efforts, and 3) the marginal gains that result from such activism. ${ }^{76} \mathrm{He}$ asserts that the apathy of shareholders is normatively a good thing, because when institutional investors are motivated to interfere with corporate governance, they usually do so in order to champion their narrow interests that undermine shareholders' interests as a whole and hamper the ability of directors to make decisions in the best interest of the firm. ${ }^{77}$

Bainbridge also explores the limits of existing vehicles for shareholder activism, including: 1) exit, 2) proxy contests, 3) withholding votes in director elections, 4) shareholder proposals, and 5) private negotiations between institutional investors and corporate management. ${ }^{78} \mathrm{He}$ asserts that shareholder primacy advocates view these vehicles as inadequate and that they are promoting expansion of the shareholder franchise by: 1) reforming the director nomination process, 2) reforming the mechanics of the voting process, and 3) expanding the substance of what shareholders can vote upon. Bainbridge flatly rejects that the expansion of shareholder voting rights would be prudent, reinforcing his main argument, which calls for adherence to the statue quo. Ultimately, he reminds his reader that one should not take lightly the dangers of interfering with board authority for the sake of greater accountability, because "the preservation of managerial discretion should always be [the] default presumption". ${ }^{79}$

\section{The MYTH AND MYSTIC OF DELAWARE: BAINBRIDGE IN CONTEXT}

\section{A. HistORICAL INTRODUCTION}

Bainbridge starts The New Corporate Governance by asking his reader to make a number of important assumptions that compliment his arguments. However, such assumptions may need more contextualization in order to assess whether or not they should be immediately conceded. One assumption in particular, which Bainbridge asks his reader to accept, is that state competition for corporate law development has lead to a "race to the top" as regards the quality of corporate governance. ${ }^{80}$ Since the cornerstone of Bainbridge's argument is grounded in a normative defense of the Delaware model, and thus the product of state competition, by

\footnotetext{
${ }^{76}$ Id. at 208.

${ }^{77}$ Id. at 209.

${ }^{78}$ For more detail on the these mechanism of shareholder voice, see id. at 209- 222.

${ }^{79}$ Id. at 235.

${ }^{80}$ Id. at $\mathrm{x}$.
} 
accepting this assumption, one tacitly accepts the primacy of Bainbridge's position from the outset. To assess whether or not one ought to do this, the following section will contextualize his request, starting with the remainder of the introduction to Part IV, which provides a historical introduction to federalism and corporate law in the $19^{\text {th }}$ century.

During the American republic's early decades, state legislatures restricted the rights of corporate action by scrutinizing petitions for incorporation as they would any other piece of legislation. ${ }^{81}$ In theory, democratic representatives granted incorporation only if it served the public interest to do so, but healthy skepticism should be reserved for anyone who claims that this was always the case. ${ }^{82}$ Restrictions on the corporation were severe by today's standards. For instance: 1) a corporation could not accumulate more than a set amount of capital, ${ }^{83} 2$ ) a corporation's life was usually fixed to the time required to finish the task(s) that it was incorporated to accomplish, ${ }^{84} 3$ ) a corporation could not engage in activities that were not explicitly defined in the terms of its incorporation, ${ }^{85}$ and 4) a corporation's business activities could not extend beyond the boundaries of the state in which it was incorporated. ${ }^{86}$

Yet in spite of such limitations, the corporation was still a coveted investment vehicle. One reason for this was that the status of shareholders was a rare and prestigious privilege. ${ }^{87}$ However, it would be misleading to conclude that this investment vehicle was desired merely because it offered a degree of social status. The main attraction to the corporation was more likely the limited liability protection it offered to businessmen ${ }^{88}$ and the opportunities for power and profits, which large "public interest" projects presented. ${ }^{89}$

\footnotetext{
${ }^{81}$ For the boundaries of government's authority over incorporation, especially after the corporate charter was issued by the state, see Trustees of Dartmouth College v. Woodward, 17 U.S. (4 Wheat.) 518 (1819). For greater detail, see Millon, Theories, supra note 52, at 206-210.

${ }^{82}$ DAvid SCIUlli, Corporations vs. The CourTs (1999) [hereinafter Sciulli, Corporations] (arguing that each request for incorporation was subject to the same lobbying and debate as any bill, including that same "power plays, personal intrigues and local favoritism").

${ }^{83}$ For a thorough collection of reference to specific legislation from the 19th century, see Liggett Co. v. Lee, 288 US 517 (1933), 550-554 (Brandeis, J., dissenting) [hereinafter Brandeis 1933].

${ }^{84}$ Almost half of the states retained limits of less than 50 years up to 1903, see id. at 555.

${ }^{85}$ Bank of Augusta v. Earle, 28 U.S. (13 Pet.) (1839) (Taney, CJ, held that since the powers conferred on the corporation can be no greater than state, which granted the incorporation, the firm had no authority to operate outside the state).

${ }^{86} I d$.

87 James Willard Hurst, The Legitimacy of the Business CORPORATION IN THE LAW OF THE UNITED StateS 1780-1970 14, 25, AND 28 (1970) [hereinafter Hurst, Legitimacy of Business].

${ }^{88}$ Horwitz, Santa Clara Revisited, supra note 52, at 208-209 (arguing that although the common law had evolved to the point of presuming limited liability, state legislatures enacted legislation to extend their shareholder liability a bit further than the value of their share).

${ }^{89}$ Millon, Theories, supra note 52, at 207 (arguing that there was fear that the potential for power and wealth associated with incorporation caused Americans to fear that such organizations could threaten the opportunity of
} 
By 1858, Americans had endured a depression and two crashes of the stock market, and also witnessed what was perceived to be the floundering public management of large interstate canal projects. These events provoked a shift in public opinion as regards the relationship between public and private power in American society, ${ }^{90}$ even if citizens did not understand their shift in opinion as such. They began viewing government intervention in private transactions less in terms of securing liberty and more in terms of restricting it. Public authorities found themselves faced with a public demanding justification for why the corporation must be a servant of public interest, and more importantly, from the individual's perspective, for why private citizens should not use such corporations solely for personal advantage in the pursuit of happiness. ${ }^{91}$ Citizens also became less trusting of government discretion in granting incorporations because accusations of favoritism and corruption within government function were more accepted as fact. ${ }^{92}$ With these changes in public opinion, the government walls that confined corporate behavior crumbled under the pressure of public opinion. Emerging state policy began to challenge the established understanding that the function of the corporation was solely to serve the community. ${ }^{93}$ This shift, in turn, opened the door for what one might consider to be an activist U.S. Supreme Court to determine that corporations had constitutional rights, which protected them from much public meddling in their affairs. ${ }^{94}$

With the loosening of state policy (and advancements in technology) ${ }^{95}$, the number of incorporations exploded. Professional management teams were hired frequently, as owners were less commonly involved in the daily operation of corporations. ${ }^{96}$ These radical transformations

others who would like to enter the market, adding that for this reason governments rarely confer monopoly privileges).

${ }^{90}$ For more on how the canals fiasco shifted public opinion, see CARTER GOODRICH, GOVERNMENT PROMOTION OF AMERICAN CANAlS AND RAILWAY (1961); and also see CARTER GOODRICH, Julius Rubin, JEROME CRANMER, AND Harvey H. SEgal, CANAls AND American ECONOMic Development 241 and 246-247 (1961), (describing what was perceived to be at the time the costly financial failures of the nineteenth century canal projects, of which almost $3 / 4$ of the $\$ 188$ million invested between 1815 and 1860 came from the public purse). For more on how the other mentioned financial crisis affected public opinion, see WiLliAm G. ROY, SociALIZING CAPITAL: THE RISE OF THE LARGE INDUSTRIAL CORPORATION IN AMERICA 71-75 (1997) [hereinafter Roy, Socializing Capital].

${ }^{91}$ Sciulli, Corporations, supra note 82 , at 89.

${ }^{92}$ Hurst, Legitimacy of Business, supra note 87, at 33-36 and 136.

${ }^{93}$ Gregory A. Mark, The Personification of the Business Corporation in American Law, 54 U. Chi. L. Rev. 1441, 1447 (1987) (arguing that changes in state incorporation policies "eliminated any notion that incorporation was a special grant from the state, even the public nature of a corporation's purpose could be classed into doubt").

${ }^{9}$ Santa Clara Country v. Southern Pacific R.R., 188 U.S. 394 (1896). For detailed understanding of the case and a detailed argument as regards the fallout from this case in America, see Horwitz, Santa Clara Revisited, supra note 52. For a contrasting point of view on some points, see Millon, Theories, supra note 52.

${ }^{95}$ See the subsection Part II of this review article entitled From Personal Capitalism to Managerial Capitalism and Beyond.

${ }^{96}$ Sciulli, Corporations, supra note 82, at 90. 
created a flood of new and complex issues into state courts, necessitating legal clarity. ${ }^{97}$ The corporate form was changing rapidly, demanding specialized legal services. This inspired the creation of specific state judiciaries to oversee corporate practice. ${ }^{98}$ Willing jurisdictions (in particular, New Jersey and Delaware) customized regulatory environments to attract those businessmen who were shopping for the most advantageous jurisdiction to incorporate their businesses. ${ }^{99}$ Such states began to fashion new management-friendly legislation, mostly because the franchise taxes, fee revenues and taxation on extra business opportunities, which followed incorporation, filled state coffers. ${ }^{100}$ These regulatory innovations were another essential component to the rise of the modern corporation.

The loosening of government policy can be highlighted as follows. In 1846, New York started a trend in state reform, blocking the legislature from creating corporations by special act, except in the rare case where the objectives for devising the corporation could not be attained under general law. ${ }^{101}$ In 1867, the US Congress expanded bankruptcy protections to include corporations. ${ }^{102}$ In 1875, New Jersey eliminated the restrictions on the corporation's ability to accumulate capital. ${ }^{103}$ In 1886 , the US Supreme Court held that the private corporation was a "natural person" under the US Constitution, ergo protected by the Bill of Rights, which broadly protected the corporations from public authority. ${ }^{104}$ In 1888, New Jersey offered the first standard articles of incorporation for private businesses. ${ }^{105}$ In one reflexive jerk away from the growing power of the mighty corporation, the Sherman Antitrust Act was signed in $1890 .{ }^{106}$ But still racing forward at the state level, in 1896, New Jersey adopted what could be recognized as the first modern corporate statutes, and thus it became the home to the majority of America's largest corporations - a title that Delaware would steal within twenty years. ${ }^{107}$ In 1910 , the

${ }^{97}$ Hurst, Legitimacy of Business, supra note 87. at 82-83.

${ }^{98}$ Id. at $82-83$.

${ }^{99}$ Lucian Arye Bebchuk, Federalism and The Corporation: The Desirable Limits on State Competition in Corporate Law, 105 Harv. L. Rev. 1437, 1443 (1992) [hereinafter Bebchuk, Federalism] (describing the pressures and incentive, which started jurisdiction competition for incorporation); and William L. Cary, Federalism and Corporate Law: Reflections Upon Delaware, 83 Yale L. J. 663 (1974), 669-670 [hereinafter Cary, Federalism] (arguing that state competition has lead to a "a race for the bottom" in terms of the standards for corporate governance - in particular to the disadvantage of shareholders).

${ }^{100}$ Curtis Alva, Delaware and the Market for Corporate Charters: History and Agency, 15 Del. J. Corp. L. 885,888 (1990); Id. at 668-669 and John C. Coffee, Jr., The Future of Corporate Federalism: State Competition and the New Trend Toward De Facto Federal Minimum Standards, 8 Cardozo L. Rev. 759, 762 (1987).

${ }^{101}$ N.Y. Const. art. VIII, $\S 1$ (1846).

${ }^{102}$ Sciulli, Corporations, supra note 82, at 91.

${ }^{103}$ Id., 91 .

${ }^{104}$ Horwitz, Santa Clara Revisited, supra note 52; and also see Millon, Theories, supra note 52.

${ }^{105}$ Roy, Socializing Capital, supra note 90, at 152-153.

${ }^{106}$ Sherman Antitrust Act, ch. 647, 26 Stat. 209, 15 U.S.C. § 1-7 (July 2, 1890).

${ }^{107}$ Bebchuk, Federalism, supra note 99, at 1443. 
Supreme Court nullified restrictions on corporate capacity to conduct business outside the states in which it was chartered. ${ }^{108}$ By 1933, Mr. Justice Brandeis, reflecting on this historical trend toward state competition in corporate law in Liggett Co. v. Lee,${ }^{109}$ expressed concern over how the fear of losing existing state revenue and the allure of earning greater state revenue was eroding the diligent construction of corporate legal development by replacing it with a permissive consumer product that pandered to powerful corporate interests.

\section{B. The First Wave: Drawing the Distinction}

In what has been called the most influential piece ever published by the Yale Law Journal, ${ }^{110}$ William Cary picked up on Brandeis's earlier concerns about state competition. ${ }^{111}$ Cary reconsidered the trends in federalism and corporate law from the $19^{\text {th }}$ century forward and declared that modern state corporate law was a product of state competition. Most importantly, this competition was attempting to attract incorporation to increase state revenues, creating a "race to the bottom" for corporate governance standards. ${ }^{112}$ His focus was on the leader of the pack in this race, Delaware, which did what was necessary for it to maintain its lead.

Cary opined that Delaware's motivation for keeping ahead in this never-ending race was that a huge portion of the small state's budget depended upon revenues from incorporations. He contended that the state was thus beholden to corporate managers, who were selecting to incorporate in Delaware. This compelled the state to offer corporate legal arrangements that would advantage these managers by allowing them a broad and unchecked authority, which made it easy for them to engage in behavior that resulted in less than optimal corporate performance. ${ }^{113}$ Cary argued that it was time for the federal government and the judiciary to "import lifting standards" that would set a level beyond which corporate standards would not be allowed to "deteriorate". 14

Three years later, in 1977, Ralph K. Winter wrote a reply to Cary's position, which by this time

\footnotetext{
${ }^{108}$ Millon, Theories, supra note 52, at 212-213.

${ }^{109}$ Brandeis 1933, supra note 83.

${ }^{110}$ Fred R. Shapiro, The Most-Cited Articles from the Yale Law Journal, 100 Yale L. J. 1449 (1991).

${ }^{111}$ Cary, Federalism, supra note 99.

${ }^{112} I d$. at 666 .

113 "Management should not be omnipotent. Corporate charters and bylaws should not be molded for it benefit." "Managements want freedom from bothersome stockholders, government agencies, public opinion and judicial review." There is definitely an anti-managerialist tone to the work and it is clear from the alarm one senses in his tone that, like Marcellus, he believes that something is rotten in the state of Denmark (in this case the state of Delaware), see id. at 668-669.

${ }^{114}$ Id. at 705 .
} 
was almost universally endorsed as a matter of fact. In the face of this general consensus, Winter boldly proclaimed that Cary was wrong, arguing that state competition should "tend toward optimality so far as the shareholders' relationship to the corporation is concerned" and thus state corporation codes, like those of Delaware, "are optimal legal arrangements". 115 Put differently, what Cary regarded as a "race to the bottom", Winter regarded as a "race to the top".

Borrowing from the ideas of Henry Manne ${ }^{116}$, Oliver Williamson ${ }^{117}$, and Armen A. Alchian ${ }^{118}$, Winter constructed an argument suggesting that since corporations need to attract capital by selling bonds and equity capital, this placed management in a position where they needed to take the interests of such financial actors into consideration. Winter wrote, "the state which 'rigs' its code to benefit management will drive debt and equity capital away", 119 and argued that although Cary was correct in assessing that managers ultimately had the consumer power to decide which jurisdiction to incorporate, managers would not select a jurisdiction that would cause their business to: 1) earn lower-than-normal returns, and/or 2) have a higher cost of capital. On the contrary, managers would select jurisdictions that did the opposite, for the sake of selfpreservation. Thus, state competition (also called the charter market) produced an optimal corporate law regime, which accurately reflected the demands that corporate constituents had for corporate governance. $^{120}$

The rationale for the charter market that causes "the race to the top" can be summated as follows. If the corporate legal regime is structured so that management cannot maximize the corporate output (profits), debt holders may make it more expensive to: 1) hold debt, and 2) raise new debt. Such a corporate legal regime will also depress stock price potential, making it more expensive to raise new capital as well as maintain optimal relations with shareholders and creditors. Such underperforming firms will become targets for takeover. The threat of takeover will create a market for managerial control. Thus, managers will have ample incentive to demand an off-therack default statutory model of corporate governance that encourages the shareholder maximization norm. Since such a default model can be assumed to be what managers are

\footnotetext{
115 Ralph K. Winter, State Law, Shareholder Protection, and the Theory of the Corporation, 6 J. Legal Studies 251, 254 (1977) [hereinafter: Winter, State Law].

${ }^{116}$ For instance, see Manne, Higher Criticism, supra note 49; Manne, in Honor of Berle, supra note 49; Henry G. Manne, Cash Tender Offers for Shares - A Reply to Chairman Cohen, 1967 Duke L. J. 231 (1967); Henry G. Manne, Our Two Corporation Systems: Law and Economics, 53 Va. L. Rev. 259 (1967); and HENRY G. MANNE AND Henry C. Wallich, The Modern CORPORATION AND SOCIAL RESPONSIBILITy (1972).

${ }^{117}$ Williamson, Corporate Control, supra note 53, at 281.

118 Armen A. Alchian and Reuben Al. Kessel, Competition, Monopoly, and the Pursuit of Pecuniary Gain, in: Aspects of LABOR ECONOMiCs 156 (NATIONAL BUREAU OF COMMERCIAL ECONOMIC RESEARCH, 1962); and Armen A. Alchian, Corporate Management and Property Rights, in: ECONOMIC POLICY AND THE REGULATION OF Corporate Securities (Henry G. Manne, ED., 1969); and Armen A. Alchian and Harold Demsetz, Production, Information Cost and Economic Organization, 62 Am. Econ. Rev. 777 (1972).

${ }^{119}$ Winter, State Law, supra note 115, at 289.

${ }^{120}$ Id. at 290.
} 
shopping for when they select a jurisdiction to incorporate, this is what state competition provides. Thus, the charter market creates a "race to the top". And not only a race to the top, but a system of legal innovation that is not compromised by political interference, which would ultimately be the result of Cary's recommendation for federal government intervention.

In conclusion, with the line of the Cary/Winter debate clearly drawn, the stage was set for the next three decades with the advocates of Cary's position representing: 1) anti-managerialism, 2) federal intervention in state competition, and 3) more centralized planning; and with the advocates of Winter's position representing: 1) managerialism, 2) unfettered state competition, and 3) more decentralized market rationality. Underpinning both positions was an understanding that the firm was no longer a political actor, like during Berle's era of Welfare statism, but rather it was transforming into a purer market actor, which focused squarely upon optimizing its potential to satisfy the shareholder wealth maximization norm.

\section{The Second Wave: Event Studies and the Attempts to Settle the Cary- WINTER DEBATE}

Winter's economic analysis of charter markets forced those from the Cary camp to adjust their arguments, by taking a more economically sophisticated position in order to counter Winter's arguments. Following Winter's lead, they argued that shareholders (and creditors) had much less control over managers' incorporation preferences in practice than Winter's charter market theory suggested. And for this reason, his "race to the top" argument was flawed. Others became inspired to settle this theoretical tit-for-tat once and for all by engaging in empirical research in the form of "event studies", which they hoped would settle the debate.

Event studies were conducted to test whether Winter or Cary was correct in his assessment of regulatory competition. ${ }^{121}$ Event studies employed a methodology, which identified a number of significant amendments to state corporate laws. Each of the amendments was selected by the researchers conducting the studies, because a link between state competition and the amendment under investigation was assumed to exist. Then the researchers collected stock market data on the corporations affected by the amendment(s). They collected this for the calendar dates on which the market was assumed to be reacting to the change in state law. This methodology determined whether such amendments had an immediate positive or negative effect on stock value. And thus, it appeared reasonable to assume that the information collected on stock value fluctuation could be used to resolve whether or not shareholders regarded the amendments as serving their interests; in other words, whether state competition was leading to a race to the top or bottom.

\footnotetext{
${ }^{121}$ Peter Dodd and Richard Leftwich, The Market for Corporate Charters: 'Unhealthy Competition' vs. Federal Regulation, 53 J. of Bus. 259 (1980); Roberta Romano, Law as a Product: Some Pieces of the Incorporation Puzzle, 1 J. of Law, Economics, and Organization 225 (1985) [hereinafter Romano, Law as a Product]; and Jeffry Netter and Annette Poulsen, State Corporation Laws and Shareholders: The Recent Experience, 18 Fin. Mgmt. 29 (1989).
} 
The common consensus in the studies was that the data indicated that a direct correlation between regulatory competition and a reduction in stock value could not be established. It was assumed that if Cary was correct, when amendments to corporate law occurred in response to state competition, shareholders would be disadvantaged. Such disadvantaged shareholders would generate less demand for the stocks affected by the amendments and a correlating fall in their value would be noticeable when the market learned of such amendments. Since there was no depression in share value, it was presumed that such amendments did not hurt shareholders. The researchers discovered that, in fact, many stocks affected by the amendments rose in value when the markets learned of the amendments. Ergo, the evidence supported Winter's position, and thus the general consensus of these event studies was that this competition was creating an optimal corporate law regime in America.

Those defending Cary's position fired back. Melvin Eisenberg rejected these event studies, arguing that they had "only limited usefulness" in the context of the Cary-Winter debate. ${ }^{122} \mathrm{He}$ contended that if a uniformly low-grade corporate law regime existed, as Cary suggested, then the notice of an amendment from "one low-grade regime to another would not be a significant event". ${ }^{123} \mathrm{He}$ also suggested that Delaware's mature case law increased predictability, helping to countervail potentially suboptimal rules and amendments to rules. More importantly, Eisenberg emphasized that other contributory factors may have skewed the results of the event studies, which were not taken into consideration. Examples of such factors included negative amendments to existing law. These often co-occurred with positive developments, including: public offerings, mergers-and-acquisitions programs, and positive amendments.

Eisenberg suggested that the positive developments "drown out any negative effect resulting from a switch to a less optimal legal regime". ${ }^{124}$ Eisenberg also suggested that negative effects of amendments might be difficult to determine, since it may not take the form of an obvious rule that encourages exploitation, but rules that merely eliminate checks on management performance. Beyond this, Eisenberg suggested that such event studies were limited because the economic analysis was so superficial that it could not adequately appreciate the complexity of the American "charter market". ${ }^{125}$ Lucian Bebchuk made similar arguments to Eisenberg rejecting the event studies as evidence of the "race to the top", again arguing how negative information can be packaged with positive information in order to maintain or improve stock value, ${ }^{126}$ and re-emphasizing the arguments, which suggested that Cary's position was still correct.

\footnotetext{
${ }^{122}$ Melvin A. Eisenberg, The Structure of Corporation Law, 89 Colum. L. Rev. 1461, 1508 (1989) [hereinafter Eisenberg, Corporation Law].

${ }^{123} I d$. at 1508 .

${ }^{124} \mathrm{Id}$. at 1508 .

${ }^{125} I d$. at 1509 .

${ }^{126}$ Bebchuk, Federalism, supra note 99, at 1449.
} 
Arguably it was Eisenberg's reply that made the most significant impact upon the event studies because he argued the more conciliatory position, at least as compared to Bebchuk, and because his economic analysis was impressive. Eisenberg contended that the event studies were based on an economic analysis, which was too superficial to appreciate the complexity of the American charter market. This appeared to affect Roberta Romano, who had written probably the most significant of these event studies. ${ }^{127}$

Within 4 years of Eisenberg's reply, Romano published possibly the best work from the Winter camp. The book was entitled The Genius of American Corporate Law. ${ }^{128}$ In it, Romano responds to Eisenberg's criticism by employing the lenses of: 1) financial risk management within equity markets, 2) agency cost theory, and 3) the relational understanding between socio-legal norms and market forces. These lenses helped to better understand the mechanics of the charter market. Romano effectively answered Eisenberg's demands for "deeper economic analysis" from the Winter camp. ${ }^{129}$

What is interesting is the similarity of the language that Romano and Eisenberg used in stating their nuanced positions on the effects of state competition on corporate law. Eisenberg wrote:

[Deeper economic] analysis shows that neither Gary nor Winter captured the actual dynamics of the charter market and leads to a position that is intermediate between those of Cary and Winter, although closer to Cary's. ${ }^{130}$

Romano mirrored Eisenberg's conclusion, but bit more aggressively in favor of her position:

The answer to the question of the efficacy of state competition is therefore between the polar positions of Winter and Cary, albeit far closer to the Winter (that is pro-state competition) than to Cary (that is, pro-federal regulation) end of the continuum ... ${ }^{131}$

At the end of the second wave of debate over the virtue of state competition, the applications of event studies to the debate appeared to bring some key acolytes of Cary and Winter closer to agreement in principle than Cary and Winter had during the first wave, which had the effect of quieting the debate somewhat ... at least for a while.

\footnotetext{
${ }^{127}$ Romano, Law as a Product, supra note 121.

${ }^{128}$ Roberta Romano, "The Genius of American Corporate Law" (1993) [hereinafter: Romano, Genius of Corporate $L a w]$.

${ }^{129}$ Eisenberg uses this language to level his criticism of the superficial nature of the event studies, see Eisenberg, Corporation Law, supra note 122, at 1509.

${ }^{130}$ Id. at 1509 (emphasizes added).

${ }^{131}$ Romano, Genius of Corporate Law, supra note 128, at 148 (emphasizes added).
} 


\section{The THIRD WAVE: Post-ENRON}

One acolyte of Cary, whose voice could still be heard in resolute protest of the pacification of positions, was that of Bebchuk. Unlike Eisenberg, he did not temper Cary's original position, despite the fact that consensus in the literature had drifted away from Cary and toward the center of the continuum. Bebchuk insisted that Cary was right, warning that state competition encouraged a race to the bottom, because states had obvious inducements (for instance, state revenue) to offer rules that were attractive to managers and controllers. ${ }^{132}$ In a persuasive argument published in 1999, Bebchuk and Allen Ferrell illustrated how anti-takeover statutes were inefficient and reduced shareholder wealth, ${ }^{133}$ providing one clear example of how states provided default rules that benefited only managers to the detriment of all other constituents, and "should lead the many who offer unqualified support of state competition to reassess their position". ${ }^{134}$ But in 1999, the US economy was hot, the inflation-adjusted aggregate output was up, real gross domestic product was up, corporate profits were up, employment was up, and everyone was making money. Bebchuk's concerns were inaudible over the sound of investors' portfolios filling with money. Corporate America seemed to be anything but broken.

In 2001, Marcel Kahan and Ehud Kamar published an influential piece that, in retrospect, marked a shift in how many viewed Delaware and the operation of the charter market. ${ }^{135}$ The authors focused on two network externalities within the process of state competition: Delaware's franchise-tax formula, and the litigation-intensive structure of its substantive law. The franchisetax formula reflected Delaware's power to exploit the demand for its legal product through price discrimination. In other words, Delaware was setting different fees to different users based upon their willingness to pay. As a result, Delaware's services were available to more firms, since wealthy incorporators subsidized poorer ones. This augmented social welfare, but as the authors observed, its litigation-intensive substantive law, which charged a high cost to those firms that engaged in legal disputes, offset this augmentation. The result was a more complex picture of Delaware as a profit focused legal system. Delaware was not a pawn of state competition, but a commanding (and more autonomous than assumed) powerbroker, which exploited the demand for its corporate law regime in a way that might not have been optimal for either managers or shareholders.

2001 also marked then end of the lionization of Corporate America, which abruptly ended as the details of Enron's shocking collapse into bankruptcy emerged. The scandal outraged Americans and pulled corporate governance under the microscope. In step with these political changes, Bebchuk warned again in 2002 that the supporters of Winter were wrong and that the empirical

\footnotetext{
${ }^{132}$ Lucian Arye Bebchuk and Allen Ferrell, Federalism and Corporate Law: The Race to Protect Managers from Takeovers, 99 Colum. L. Rev. 1168, 1170 (1999).

${ }^{133} \mathrm{Id}$.

${ }^{134} I d$. at 1199 .

${ }^{135}$ Marcel Kahan and Ehud Kamar, Price Discrimination in the Market for Corporate Law, 86 Cornell L. Rev. 1205 (2001).
} 
evidence supported the view that state competition offered harmful incentives, which privileged managers to the detriment of all other corporate constituents. ${ }^{136}$

In another piece published in 2002, Bebchuk and Assaf Hamdani attacked the suggestion that state competition was occurring at all. This piece was following the recasting of Delaware introduced by Kahan and Kamar. Accordingly, Bebchuk and Hamdani argued that Delaware's position in the charter market was so strong that assumptions about the operation of state competition were false. In other words, they reinforced the suggestion that Delaware was more sheltered from the influence of other states' actions than was assumed in the literature, producing suboptimal corporate rules and justifying federal intervention. ${ }^{137}$

In the summer of 2002, the federal government induced aggressive measures to appease populist reactions to the Enron Scandal. Suddenly, there was a rash move toward Cary's federal intervention that may have been procedurally pleasing to some corporate governance observers, but was ultimately substantively disappointing to most. With this came renewed interest in the Cary-Winter debate.

Soon after these events, Mark Roe reconsidered the debate, offering some fresh insight, ${ }^{138}$ which seemed to build on the nuanced recasting of Delaware in the literature by Kahan and Kamar, and by Bebchuk and Hamdani. Roe concluded that the nature of corporate regulatory competition had been "misconceived - and badly so", arguing that Delaware's chief competition was never other states, but the federal government. ${ }^{139}$ Other states did not have the constitutional authority to trump Delaware's default rules for corporate governance, but the federal government did. In other words, Delaware's incorporation regime existed because the federal government tolerated it. So, the results of corporate law evolution may have been due in part to state competition, but the ever-looming threat of federal intervention was also a major factor. Which of these two factors affected the evolution of corporate law was difficult to determine because the world of Delaware policymaking was opaque.

Roe further suggested that if federal-Delaware competition was taken into consideration when attempting to understand the traditionally conceived mechanism of state competition, the state race debate did not play out the way charter market analysis assumed ${ }^{140} \mathrm{He}$ suggested that a new theory was necessary to explain how policy networks forged American corporate law, arguing that top-down "centralized strategic" planning had as much responsibility for corporate law

\footnotetext{
${ }^{136}$ Lucian Bebchuk et al., Does the Evidence Favor State Competition in Corporate Law?, 90 Cal. L. Rev. 1775 (2002).

${ }^{137}$ Lucian Arye Bebchuk and Assaf Hamdani, Vigorous Race or Leisurely Walk: Reconsidering the Competition over Corporate Charters, 112 Yale L.J. 553 (2002) [hereinafter Bebchuk and Hamdani, Reconsidering the Competition].

${ }^{138}$ Mark J. Roe, Delaware's Competition, 117 Harv. L. Rev. 588 (2003).

${ }^{139}$ Id. at 591.

${ }^{140} I d$. at 646 .
} 
outcomes as did lateral state competition. ${ }^{141}$ Upon reflection, if Roe was right, it would make sense that the federal political dimension would compromise the narrow quest for solely understanding state competition through the assumed model of charter markets as constructed during the second wave of the debate.

In 2003, Bainbridge threw his hat in the ring, taking a position as far to the Winter end of the continuum as Bebchuk took to the Cary end of it. ${ }^{142}$ In an article he wrote for Regulation Magazine, which is published by the Cato Institute, Bainbridge blasted the federalization of corporate law, calling the actions of Congress and other regulators "deeply flawed". ${ }^{143}$ He argued that since the Enron Scandal, the actions of the federal government represented "the most dramatic expansion of federal regulatory power over corporate governance since the New Deal". ${ }^{144}$ Bainbridge rejected the federal reforms as an unnecessary encroachment on state jurisdiction. He pointed to Romano's event study to establish his claim that state competition and Delaware's default rules favored shareholders by maximizing shareholder wealth, ${ }^{145}$ tacitly suggesting that the federalization of corporate law was not placing shareholders' interests in jeopardy. When addressing Bebchuk's 1999 argument about the negative effects of state competition upon shareholder wealth by legislating anti-takeover statutes, his response was "so what ... nobody claims that state competition is perfect". ${ }^{146}$ He also proclaimed that "even if Bebchuk could prove that state competition is a race to the bottom, basic principles of federalism would still counsel against federal preemption of corporate law", because the potential for regulatory innovation would be seriously compromised. ${ }^{147} \mathrm{He}$ concluded that Congress should "back off" and "pay due respect to the principles of federalism that have governed corporation law since the New Deal". 148

A reader is left wondering what to think of this op-ed like article, for the usually careful Bainbridge appears to be throwing rhetorical haymakers. One must remember the nature of the publication and assume that he was hoping to appeal more to the emotions of a libertarian audience than to the intellect of an academic one. That said, if Bainbridge and Bebchuk were the new poles of the state competition debate, and if Roe was floating on the periphery on the debate, it appeared that the fence-mending that may have occurred between Romano and Eisenberg may have been for not, because the Cary-Winter debate was now as polarized and as contested as ever.

\footnotetext{
${ }^{141} I d$. at 646.

${ }^{142}$ Bainbridge, creeping federalization, supra note 7.

${ }^{143} I d$. at 26.

${ }^{144} \mathrm{Id}$. at 26 .

${ }^{145} I d$. at 30 .

${ }^{146} I d$. at 30 .

${ }^{147} \mathrm{Id}$. at $30-31$.

${ }^{148} I d$. at 31 .
} 
In Roe's second article on the topic, he still insisted that the federal government had the power to crush Delaware's corporate law regime whenever and however it chose. ${ }^{149} \mathrm{He}$ insisted that American scholars ought to recognize this more clearly and then reconsider the presumptions embedded within the Cary-Winter debate. These presumptions on state competition were skewing the perception of American corporate law observers in his opinion. He believed that instead of looking at the results of horizontal state competition to understand the development of corporate law, observers needed to understand when the federal government decided to leave such authority in the hands of the states and when it decided to claw back such authority for itself.

He suggested that understanding the principles, political interests and institutional structures that determine federal choices in this matter provided an opportunity to understand the nature of corporate governance in America. ${ }^{150} \mathrm{He}$ described Delaware as a political group with basically shared concerns (or at least a narrowly defined range of concerns) within the larger policy network of corporate law development. ${ }^{151} \mathrm{He}$ argued that Delaware's policymaking network was like a caucus of managers and investors, which enjoyed the preeminent position within the mechanism of corporate policy development in America. Moreover, this caucus was granted a tremendous capacity to control corporate legal status quo. Roe suggested that unless Congress was called upon to act (whether because of the demands of managers, investors or a groundswell of populous backlash inspired by crisis or scandal), the presumption was that federal policymakers would leave corporate legal innovation to the states, which in effect blocked broader public policy interests from being introduced into American corporate law. ${ }^{152}$

Roe contended that the federal-Delaware arrangement acted as a check on state authority by deterring the introduction of highly contentious corporate regulations. Such radical amendments could tip the balance by alienating an influential political group at the federal level, which could trigger a federal intervention. If this happened, then it might limit the capacity of Delaware to shape an aspect of "its" corporate law in the future by permanently limiting the authority of its caucus. This was unlikely to happen because Delaware's ambit of discretion was too valuable to risk.

Within the caucus, Roe deemed that managers clearly had the "upper hand" in guiding policy development, but they also appeared to exercise self-constraint, because they understood "the game could move to Washington" if the scales were pushed too far toward managerialism. ${ }^{153}$

\footnotetext{
${ }^{149}$ Mark J. Roe, Delaware's Politics, 118 Harv. L. Rev. 2491, 2494 (2005) [hereinafter Roe, Delaware's Politics].

${ }^{150}$ Id. at 2494.

${ }^{151}$ Roe uses the work "caucus", but the power of this label is more significant when it is clearly defined, see id. at 2494.

${ }^{152} I d$. at 2494.

${ }^{153} I d$. at 2542.
} 
This was Roe's second attempt in the Harvard Law Review to shift the debate, but shifting it was difficult in the pre-Credit Crisis world where "the market" was still the answer and the charter market lens was still the most ideologically appealing mode of analysis of corporate legal development.

In an article released the same year as Roe's, Leo E. Strine, Jr., Vice Chancellor of the Court of Chancery in Delaware, published a modified version of a lecture he gave at the European Policy Forum in July 2005. His goal was to "take some of the mystery out of Delaware's role in the governance of American public corporations". ${ }^{154}$ Strine provided a good history, structure and function of Delaware's corporate law regime. But regarding the politics of state competition, Strine was reserved. Alluding to the fact that Delaware was and will be in the lead for some time to come in the state race for corporate law, he proclaimed that the American system of federalism had constructed a "national corporate law-i.e., that of Delaware", which facilitated wealth creation far better than if Congress had attempted to manufacture it. ${ }^{155}$ Not surprisingly, Strine was a champion of the Winter position.

Without making reference to actual constitutional power of the federal government, Strine discussed what could be called the constitutional conventions of the division of power between the federal government and the states in relation to corporate law development. He stated that the issues of competition, labor, trade, and disclosures to public investors were generally regulated federally, while Delaware governed the "internal affairs of the corporation". ${ }^{156} \mathrm{He}$ argued that Delaware was a better de facto national corporate law regime than the federal government could provide. ${ }^{157}$ Throughout the article, although he came to a number of points in his argument where it appeared obvious that he ought to acknowledge the elephant in the room, he never more than tacitly acknowledged that the federal government had full authority to regulate the internal affairs of the corporation, if it so chose. ${ }^{158}$ In other words, he failed to directly acknowledge that Delaware's power was a privilege granted to the state by the federal government and not a constitutional right. As Roe pointed out, this is an incredibly important aspect of policy development in Delaware, but Strine does not elaborate on this federal pressure other than to say that present interventions like The Sarbanes-Oxley Act and the amendments to listing requirements were suboptimal reforms that proved to be bad for all constituents of the firm.

Strine's silence on this issue speaks volumes to what was at stake in the Cary-Winter debate. This challenges a corporate observer to reflect upon why this Vice Chancellor was so detailed on

\footnotetext{
${ }^{154}$ Leo E. Strine, Jr., The Delaware Way: How We Do Corporate Law and Some of the New Challenges We (and Europe) Face, 30 Del. J. Corp. L. 673, 673 (2005).

${ }^{155} \mathrm{Id}$. at 673-674.

${ }^{156} \mathrm{Id}$. at 674.

${ }^{157} I d$. at 683 .

${ }^{158} I d$. at 686 .
} 
other aspects of his goal to "take some of the mystery out of Delaware's role in the governance of American public corporations", ${ }^{159}$ but did not elaborate upon this key aspect of policy development at the state level. It appeared that prior to the Credit Crisis, American corporate governance actors and observers from the Winter camp were reluctant to acknowledge the role of the federal government in the "charter market".

In the third wave, marked by a creeping federalization of corporate law, the distinctions within the Cary-Winter debate were renewed. Bebchuk refused to compromise and when the ground started to shift away from the "race to the top" theory, some like Bainbridge came out swinging. Roe attempted to expose some significant flaws in the construction of this dichotomy, but other key players in the literature appeared to have strongly developed priors about the centrality of Washington as a real and potential maker of corporate law, and failed to adequately deal with Roe's challenge. This was evident in the conspicuous absence of any mention of the Roe Factor in Vice Chancellor Strine's demystification of Delaware's role in American corporate governance.

\section{E. The Delaware Dynamic: Berle-Dodd, Berle-Manne, Cary-Winter, RoMANO-EISENBERG, BEBCHUK-BAINBRIDGE, AND STRINE? AND RoE? AND BRATTON?}

In sum, before Berle and Dodd and the modern corporation, owners had their business operations on a short leash, but when the functional complexity and dispersion of ownership emerged as the norm at the beginning of the twentieth century, professional managers easily usurped corporate power and mostly with the blessing of ownership. For Berle, shareholder primacy was a less than ideal measure to control the freewheeling excesses of managerial opportunism, but in the interim, it was the best option available. For Dodd, Berle's shareholder primacy smothered the potential of enlightened managerial behavior and thus corporate social responsibility.

For Berle, the shareholder class was the American Everyman. For Dodd, it was an exploitive class of elites, who were solely and dangerously driven by profit. For Manne, shareholder primacy was key to a market mechanism that could control managerial behavior and he took it very seriously. For Manne, the shareholder class had the collective wisdom to guide corporate affairs optimally. For Cary, shareholders were getting shortchanged because states like Delaware needed the revenues associated with incorporation and thus needed to cater to their customers, who were those making decisions about incorporation - managers. This created a race to the bottom, if the prize was shareholder wealth maximization. For Winter, managers wanted shareholder wealth maximization as much as shareholders did, thus what Cary called a "race to the bottom" was actually a "race to the top". Romano and Eisenberg reduced the distance between the positions of Winter and Cary, but Bebchuk and Bainbridge re-heightened the

\footnotetext{
${ }^{159} I d$. at 673 .
} 
distinction. For Bainbridge, the primacy of Delaware and state competition had to be protected. For Bebchuk, the federal government had to intervene in the operation of Delaware, if managerialism was to be checked and shareholder rights were to be protected.

For Roe, the state competition lens was inadequate for understanding the policy network of corporate lawmaking in America. Bebchuk seemed to agree when he argued that Delaware was sheltered from state competition. But Bebchuk and Bainbridge did not appear to give Roe's arguments the consideration they were due, and neither did Strine. The reason may be because there is a lot at stake: the primacy of Delaware. So, what was Delaware? Strine told part of the story and Roe told the rest. Strine explained that Delaware's corporation law was not "a broadbased company law" (excluding issues of competition, labor, trade, and disclosure to public investors), focusing solely on the "internal affairs of the corporation". "It was a "specialized form of contract law" that governs "the relationship between corporate managers - the directors and officers - of corporations, and the stockholders". ${ }^{161}$ The federal government dealt with the rest. Strine argued that Delaware was de facto America's national corporate law. ${ }^{162}$ Bebchuk agreed, but he lacked the enthusiasm of Strine, seeing it as placing power over corporate law firmly in the hands of corporate managers at the expense of shareholders. ${ }^{163}$

Roe explained that Delaware amounted to a monopoly of power over "national" corporate law development: a monopoly that was in the hands of mainly managers, but also to shareholders to a lesser degree. ${ }^{164}$ This political caucus was always attempting to keep the larger policy network of the federal government at arm's length. Bebchuk emphasized that Delaware was in the hands of managers. Roe agreed, but he believed that managerial self-interest was mitigated by the threat of federal intervention. It is possible that Bainbridge may even have agreed, but the difference was that Bainbridge insisted that managers (directors) were already serving the best interests of shareholders, so this situation was optimal. Bebchuk insisted that the federal government needed to step in.

So what else is at stake in Delaware? It is the American corporate governance status quo. And what sort of a world does this status quo sustain? At this point, I am turning my focus upon the thoughts of William Bratton, who is one of the finest American corporate scholars, but is also a maverick who appears willing to upset the apple cart. He suggests that the Delaware status quo is a world where the baseline criterion for corporate action is profitability; ${ }^{165}$ a world where when the higher sense of legitimacy conflicts with profitability, the latter wins out. It is a world where

\footnotetext{
${ }^{160} I d$. at 673 .

${ }^{161} I d$. at 673 .

${ }^{162} I d$. at 673-674.

${ }^{163}$ Bebchuk and Hamdani, Reconsidering the Competition, supra note 137.

${ }^{164}$ Roe uses the work "caucus", but the power of this label is more significant when it is clearly defined, see Roe, Delaware's Politics, supra note 149, at 2494.

${ }^{165}$ Bratton, Welfare, Dialectic, and Mediation, supra note 57, at 71.
} 
a "bright line", which separates insiders from outsiders, has replaced legitimated responsibility, coolly rationalizing the privileges of the former. ${ }^{166}$ It is a world where the public/private distinction creates the opportunity to assert that corporate law should not engage in many public interest matters, by operating under the assumption that backstop federal regulations will protect the public interest. ${ }^{167}$ It is a world where "formalism prevails, making winners of the empowered" while the jurisprudence "smirks in its complicity". ${ }^{168}$ It is a world where "winning has its privileges and optimality is always Kaldor-Hicks". ${ }^{169}$ It is a world where, ironically, the poor and disenfranchised majority buys into this status quo, endorsing corporate law's "lack of evenhandedness", so long as their children may one day make their way into "the winner's circle". ${ }^{170}$ High poetry yes, but there is a discomforting air of truth about his observations. But is there a better option? That may be a more difficult question to answer.

\section{F. THE BATTLE FOR “DELAWARE”: FORM OR SUBSTANCE?}

Strine was obviously opposed to more federal meddling within Delaware's national corporate law regime. And Bainbridge was also a defender of the Delaware status quo. But, by encouraging greater federalization of corporate law, Bebchuk appeared willing to risk Delaware's caucus and the American corporate law status quo in order to gain greater shareholder power. Although Bebchuk did not appear to want to open the Delaware arrangement to the flood of other interests that might follow the federal government into the internal affairs of the corporation, he was willing to risk it for greater shareholder empowerment.

In "The Case for Increasing Shareholder Power", Bebchuk used empirical evidence to establish that the power between directors and shareholders of larger American corporations with dispersed ownership was too unbalanced, blocking shareholders from maximizing shareholder value when management refused to cooperate with them. ${ }^{171}$ By allowing shareholders to be directly involved in corporate decision-making, Bebchuk argued that this would enhance corporate governance by motivating management to be more cooperative, simply by granting shareholders the power to threaten to directly intervene. He suggested that this power would be enough and shareholders would not actually need to intervene. How should such reforms be introduced? Bebchuk predictably stated that it should be through federal invention, because managers dominated state law, so the federal government must step up and do something. ${ }^{172}$

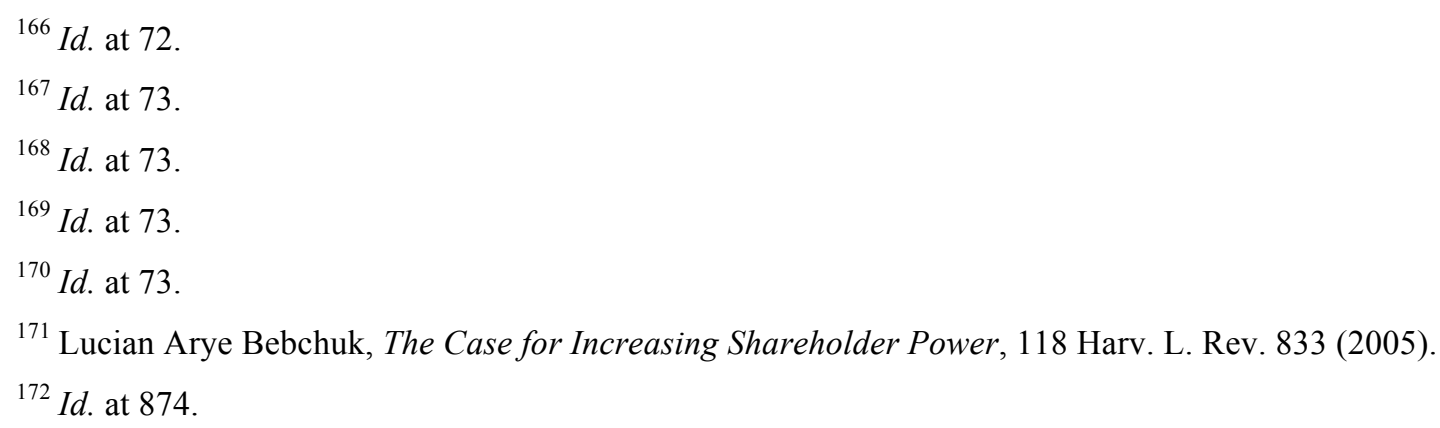


Bebchuk's writing indicated that he did not want to open the floodgates for other interests beyond shareholders and managers, which influenced the federal government. If he did not want these populous interests to start meddling in the internal affairs of the corporation, what was he doing? It was without a doubt that he was familiar with Roe's position on the matter, so maybe he did not believe that his petition for federal involvement seriously threatened the Delaware caucus, or maybe he did not care if the Delaware caucus was threatened (if managers monopolized it), or maybe he was using the Cary card as leverage to up the stakes and maybe make Delaware concede without federal intervention. Regardless, the Cary card caused different reactions, which were interesting to observe play out.

In response to Bebchuk's proposal, Strine suggested that the traditionalist investor would prefer the status quo than to what Bebchuk proposed. This was because the traditionalist investor would fear that Bebchuk's proposal would subvert their interests by compromising managerial authority. ${ }^{173}$ If managerial authority was undermined, institutional intermediaries with no interests to serve but their own would further compromise the corporate governance structure. Strine suggested that the traditionalist investor would thus "leave things where they [stood] even if the status quo [was] not ideal". ${ }^{174}$ But Strine still entertained Bebchuk's proposal, with some slight reframing of it, in order to be "open-minded" to the idea that the traditionalist investor "might embrace reform that [was] consistent with Bebchuk's call for greater managerial accountability". ${ }^{175}$ Strine bit Bebchuk's bait, but why? The answer came when Strine asserted:

Therefore, if reform attractive to the traditionalist is to come, it must emanate from state policymakers who can implement a reform that coheres with an overall approach to corporate law. ${ }^{176}$

Strine took a number of pages to make this argument, reinforcing this key point that he wanted to get across in his reply to Bebchuk. The point was that whatever amendments needed to be made, Delaware (and not the federal government) ought to be "the primary source of substantive corporate law" reform. ${ }^{177}$

Strine offered hope to Bebchuk that there might be flexibility on the issue of shareholder empowerment, but Delaware needed to be the innovator not the federal government, because state competition must be preserved. It made sense that if the choice was between Delaware

${ }^{173}$ Leo E. Strine, Jr., Toward a True Corporate Republic: A Traditionalist Response to Bebchuk's Solution for Improving Corporate America, 119 Harv. L. Rev. 1759, 1775 (2006).

${ }^{174}$ Id. at 1775.

${ }^{175} I d$. at 1775 .

${ }^{176} \mathrm{Id}$. at 1777 .

${ }^{177} I d$. at 1780 . 
(form) and the status quo (substance), Strine would advocate sacrificing some substance and managerial power, and protecting Delaware's de facto preeminence. This was probably ideal for Bebchuk, if this situation was to arise, because it would maintain Delaware's influence (blocking interests other than shareholders and managers), while increasing shareholder influence within the political caucus.

As one might expect, Bainbridge did not exhibit any of the potential flexibility that Strine did. He flatly rejected Bebchuk's proposal by arguing that if it could really enhance the value of the firm as much as Bebchuk suggested, why did it not exist already? In challenging Bebchuk in this manner, Bainbridge employed a classic Winteresque "race to the top" argument. ${ }^{178}$ In other words, the corporate law that existed was optimal because it survived the competitive forces of the charter market. He then made his director primacy argument (also found in the book), defending why this model was the appropriate model to protect shareholder interests. He concluded that since director primacy was the superior model and since Delaware's default rules already enshrined director primacy, no reform was necessary. The bottom line was that Bainbridge rejected any changes to the form or the substance of Delaware's law and lawmaking capacity.

In reply, Bebchuk was somewhat encouraged by Strine's opinions (although he believed that they did not go far enough). ${ }^{179}$ As regards Bainbridge, Bebchuk focused upon refuting his response. He attacked his "race to the top" argument by referencing the Winteresque arguments of Dennis Carlton and Daniel Fischel in an article they wrote, which found fault with the curbs on insider trading that federal government introduced in the early $1980 \mathrm{~s} .{ }^{180}$ In that article, the pro-Winter authors argued that since the state law did not prohibit insider trading, there was nothing wrong with the existing standards for it, otherwise charter competition would have already weeded it out. Accordingly, the federal prohibitions would be suboptimal. History proved otherwise. Using this example, Bebchuk illustrated the fallacy of the assumption that state competition already provided optimal corporate governance arrangements like Bainbridge was suggesting. ${ }^{181}$

Bebchuk rejected Bainbridge's argument that state competition increased shareholder value. ${ }^{182}$ But in an interesting twist, he argued that even if one assumed the arguments supporting the claim that Delaware corporate law production was optimal, just because current Delaware law did not support his proposition did not mean that it ought to be rejected outright. He pointed out that the innovative nature of state competition necessarily implied that state law was subject to

\footnotetext{
${ }^{178}$ Bainbridge, Director Primacy, supra note 8, at 1737-1742.

179 Lucian Arye Bebchuk, Reply: Letting Shareholders Set the Rules, 119 Harv, L. Rev. 1784, 1796 (2006) [hereinafter Bebchuk, Reply].

${ }^{180}$ Dennis W. Carlton and Daniel R. Fischel, The Regulation of Insider Trading, 35 Stan. L. Rev. 857, 894-895 (1983).

${ }^{181}$ Bebchuk, Reply, supra note 179 , at 1805.

${ }^{182}$ Id. at $1807-1808$.
} 
improvement in an evolving context. ${ }^{183}$ In fact, this argument may be directed more to the flexible Strine than the inflexible Bainbridge. But after his brief flirtation with Strine and the Winter position, Bebchuk then re-played the Cary card by laying out a number of arguments to support federal intervention before concluding.

\section{CONCLUSION}

\section{A. Putting the Pieces together}

Putting the pieces together provides the context for Bainbridge's book. Today, in the battle over corporate governance between insiders within the microcosm of their Delaware caucus, there appears to be an impasse, which allows managers to have the luxury of a heavy hand in shaping the evolution of corporate governance. Bebchuk, champion of the shareholder and of Cary (to a lesser degree), is unhappy with this state of affairs and is petitioning federal intervention to shake things up. Strine, champion of Winter and managerialism (to a lesser degree), is happy with Delaware's position as the manufacturer of "national" corporate law and appears "irritated" (in the Luhmannian sense of the verb) by Bebchuk's position. And Bainbridge is the warrior of the Delaware status quo and is deeply entrenched in his position. Or is he? For, although he initially attacked creeping federalism he now uses the provision of Sarbanes-Oxley Act and the amendments to listing requirements (which reinforce director independence) to support his director primacy argument. ${ }^{184}$ So maybe this suggests that his "race to the top" argument, at times, gives way to pragmatism, as does Strine's defense of the Delaware status quo. And what about the Roe Factor? If the state competition debate does not reflect the nature of corporate lawmaking in America, then aspects of these key players' arguments may have to be reconsidered.

Where the strength lies within Bainbridge's position is where he has re-invented the managerialist position as the centrist one, which can appeal to some managerialists and some anti-managerialists. By taking the shareholder/manager dichotomy and cutting it into a shareholder/director/manager trichotomy, he can place directors firmly in the middle of the struggle between ownership and control. The genius of his position is that this is what American law has de jure attempted to enforce since the rise of the modern corporation and this is how a corporation ought to operate from this frame of reference. However, history proves that American directors have not always lived up to the model of corporate governance on the books. In The New Corporate Governance, Bainbridge claims that American directors are undergoing a transformation. But is this true? For Bainbridge, this is the million-dollar question. If they are

\footnotetext{
${ }^{183} \mathrm{Id}$. at 1808 .

${ }^{184}$ Bainbridge, Corporate Governance, supra note 3, at 176-187.
} 
becoming more than "rubber stamps", then his director primacy will have wings.

In light of this, when reading The New Corporate Governance or assigning it for reading in the classroom, what one should not do is take Bainbridge's advice. In his preface, he suggests, "I ask the reader to assume for the sake of argument that the race to the top is generally valid". ${ }^{185}$ To assume this is to loose all the polemic richness of what the American corporate governance debate is about. If one assumes Winter is right, then one surrenders Bebchuk, Cary, parts of Manne and the misconstrued legacy of Berle from the outset and Bainbridge's arguments appear positive, non-normative and uncontroversial. Making such assumptions would not do justice to an account of the war that has been waged and is still raging on the pages of America's law reviews throughout the twentieth century up to today.

The New Corporate Governance is at the heart of what is happening in the American corporate governance debate today. If one wants an introduction to director primacy and a strong normative defense of Delaware's corporate law, this book will provide this information to yourself or to your class.

Is the book and its theory of director primacy the answer for shareholders? When Berle published "Corporate Powers as Power in Trust" in 1931, he intended shareholder primacy to be an interim measure until a more adequate understanding of corporate property could assist in corporate legal development. ${ }^{186}$ In his 1932 reply to Dodd and again in the Modern Corporation and Private Property, he called out for such a theory to be devised and he believed that this theory of corporate power would come soon after. But years later (from his Post-Roosevelt years until his death in 1971) Berle was disillusioned that his call was never answered and this book was never written. ${ }^{187}$ Has Bainbridge answered Berle's call? Can shareholder primacy finally be put to rest? Or is this even the right question to be asking? I guess we will have to keep reading the law reviews to find out.

\footnotetext{
${ }^{185}$ Id. at $\mathrm{x}$.

${ }^{186}$ See footnote 35 .

${ }^{187}$ See comments of Berle from the minutes of the Special Meeting of Board of Trustees of the Twentieth Century Club, June 5, 1951 reproduced, in: Schwartz, Berle, supra note 26, at 354. For examples of his lament for the lack of greater understanding of corporate power in his later writing, see Adolf A. Berle, Jr., The Theory of Enterprise Entity, 47 Colum. L. Rev. 343, 344-345 and 358 (1947); Berle, Capitalist Revolution, supra note 52, at 21; AdOLF A. Berle, JR., Power Without Property 78 (1959); and Berle, The Corporate System, supra note 55, at 449.
} 